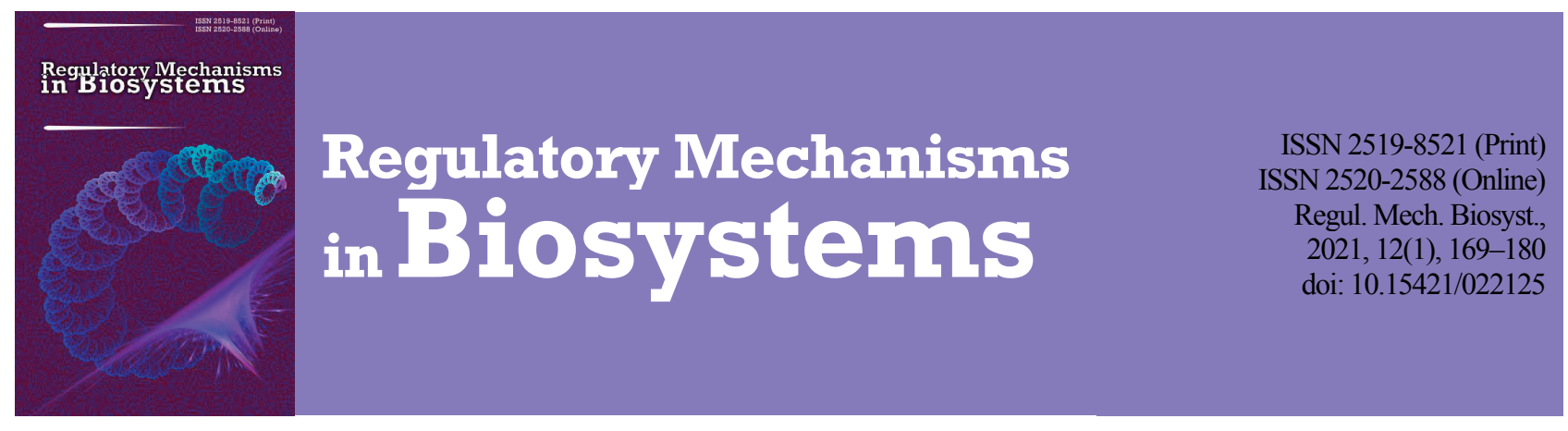

\title{
Influence of Lavandula angustifolia, Melissa officinalis and Vitex angus-castus on the organism of rats fed with excessive fat-containing diet
}

\author{
M. A. Lieshchova*, V. V. Brygadyrenko*, ** \\ *Dnipro State Agrarian and Economic University, Dnipro, Ukraine \\ **Oles Honchar Dnipro National University, Dnipro, Ukraine
}

Article info

Received 27.01.2021

Received in revised form 24.02.2021

Accepted 25.02.2021

Dnipro State Agrarian and Economic University Serhii Efremov st., 25 Dnipro, 49600, Ukraine. Tel.: +38-067-256-24-86 E-mail:

lieshchova.m.o@dsau.dp.ua

Oles Honchar Dnipro National University,

Gagarin av., 72,

Dnipro, 49010, Ukraine.

Tel.: +38-050-93-90-788

E-mail:brigad@ua.fm

Lieshchova, M. A., \& Brygadyrenko, V. V. (2021). Influence of Lavandula angustifolia, Melissa officinalis and Vitex anguscastus on the organism of rats fed with excessive fat-containing diet. Regulatory Mechanisms in Biosystems, 12(1), 169-180. doi:10.15421/022125

Plant food additives are becoming more and more popular and broadly applied products, though the information on risks they poses to the organism is limited and contradictive. Obesity and overeating are some of the commonest health issues around the world, and people are increasingly consuming workability-enhancing preparations as a simple and fast method of weight control. The plantbased preparations are considered less harmful than the synthetic chemical ones. Lavandula angustifolia Mill., Melissa officinalis L. and Vitex angus-castus L. are broadly used as food additives and medicinal plants, despite the fact that their complex physiological assessment on model animals in the conditions of obesity has not yet been performed. We carried out a 30-day experiment on white male rats. All the animals were given high-fat diet, and the experimental animals, in addition to this diet, received $5 \%$ crumbled dry herbs of $L$. angustifolia, $M$. officinalis or $V$. angus-castus. Taking into account the overall amount of consumed food, the mean daily gain in body weight; at the end of the experiment, we determined the index of the weight of the internal organs, biochemical and morphological blood parameters. At the beginning and the end of the experiment, the rats were examined for motor and orienting activities, and emotional status. Rats on high-fat diet gained up to $112 \%$ body weight by the end of the experiment, while rats that had received $V$. angus-castus gained up to $119 \%$, M. officinalis - 135\%, L. angustifolia - 139\%, compared with the initial body weight. Addition of medicinal plants to the diet led to increase in average daily weight increment, significantly and reliably after consuming lavender and lemon balm, less significantly and unreliably after eating Vitex. L. angustifolia and M. officinalis reduced the relative brain weight, and ingestion of $L$. angustifolia and M. officinalis caused notable decrease in the relative mass of the thymus (down to $58 \%$ and $47 \%$ of the relative weight of thymus in animals of the control group respectively). Also, these plants decreased the motor and orienting activities of the rats by the end of the experiment. As for the biochemical parameters of blood, the activity of alkaline phosphatase significantly increased to $406 \%$ following consumption of Melissa, to $350 \%$ after consuming lavender, and to $406 \%$ after Vitex, compared to the control group. Furthermore, all the groups were observed to have increased AST and ALT activities. Intake of lavender led to increases in cholesterol (to 125\%) and LDL cholesterol (to 228\%), whereas the groups that consumed lemon balm were observed to have decreases in urea nitrogen (to 79\%), totalbilirubin (to 63\%) and triglycerides (to 63\%). Addition of Vitex led to increase in the index of aterogenecity against the background of notable fall in HDL cholesterol (to $52 \%$ of the control group). The medicinal plants also contributed to the normalization of the glucose level. Morphological analysis of blood revealed no significant changes, except heightened content of monocytes in blood, which is characteristic of all groups, including the control. Effects of $L$. angustifolia, $M$. officinalis and $V$. angus-castus on the organism of rats on excessive-fat diet require additional histological, histochemical and immunological surveys.

Keywords: relative mass of the organs; increase in the body weight; high-fat diet; high-calorie diet; obesity; phytopreparations; motor activity; orienting activity; emotional status; biochemical blood parameters.

\section{Introduction}

Metabolic diseases such as diabetes mellitus and dyslipidemia occur due to a complex of genetic predisposition and environmental factors. Lifestyle and diet contribute to their development as well, causing significant compliations, malfunctioning and failure of brain, heart and other organs, and likely death. Despite the fact that the authorized medicines may be efficiently used to control blood glucose and cholyterol levels, they also may cause deleterious side effect. Thus, treating metabolic diseases requires seeking new agents for development of novel preparations (Heghes et al., 2020). Against the backround of obesity, metabolic diseases such as dyslipidemia, atherosclerosis and type 2 diabetes have become health problems at the global level (Shin \& Yoon, 2020). Course of obesity is attributed to angiogenesis and extracellular matrix (ECM) remodeling. Angiogenesis develops in adult adipose tissues (Arika et al., 2019;
Lieshchova et al., 2019, 2020). Adipose tissue is closely related with the blood vessels. In fact, adipocytes tissue contains have extensive systems of capillaries. Adipocytes generate endothelial growth factor A and fibroblast growth factor 2 , both proangiogenic factors driving the neovascularization of the tissue. Moreover, development of the adipose tissue and maturation of microvessels is greatly contributed by matrix metalloproteinases (MMPs), including MMP-2 and MMP-9, which modify the ECM. Therefore, modulating angiogenesis and MMP activity could likely be therapeutic means of controlling obesity and accompanying impairments (Shin \& Yoon, 2020).

Application of medicinal plants may help to decrease body weight during obesity and other metabolic disorders (Martin, 2019; Bukvicki et al., 2020). Most often, for those purposes, the treatment involves plants of Lamiaceae family (Michel et al., 2020). Zvezdina et al. (2020) have made a review of 71 species from 30 genera of Lamiaceae family, and 
drew the conclusion that the immense potential of plants of this family is still unexplored. These valuable medicinal plants could help in development of neurotropic preparations. Biologically active substances of Lamiaceae plants comprise phenolic compounds, chiefly phenolcarboxylic and cinnamic acids and their derivatives, flavonoids, including flavones, isoflavones, flavanols, flavanones, flavanones, flavans, flavans 3,4-diols, catechins, biflavonoids and proanthocyanidins (Milevskaya et al., 2019). Rich in biologically active compounds (BAC), species of Lamiaceae family are broadly used in pharmacology.

Melissa officinalis L. is a perennial herbaceous plant of Lamiaceae family. It can reach $150 \mathrm{~cm}$ in height. Its is considered to have been originated from the territory spanning from the Eastern Mediterranean to Iran, Central Asia, the Black Sea and Western Asia, and also North Africa. Currently, this plant is cultivated ubiquously for its essential oil. Content of essential oil ranges $0.02-0.20 \%$, only seldom reaching $0.80 \%$. Content of essential oil in the herbs is $0.06-0.13 \%$, and $0.39-0.44 \%$ in the leaves. Leaves and young shoots of lemon balm that had been cut before blooming are used as spices in the European and American quisines. Fresh and dried, they are added to salads, cheese, soups, meat, fish dishes, mushrooms, tea, vinegar, liquors, salting of cucumbers and tomatos (Shakeri et al., 2016). Furthermore, essential oil of Melissa, similarly to other species of plants considered in this article, has for a long time been used to eliminate or scare off storage pest insects (Martynov et al., 2019a, 2019b). The essential oil's most distinctive constituents are monoterpens citral (geranial + neral), geraniol, nerol, citronellol, citronellal. Essential oil of lemon balm also contains linalool, geranilacetate, myrcene, para-cimol, $\beta$ caryophyllene oxide, $\beta$-caryophyllene and other terpenoids. More than 200 constituents of the essential oil have been described, including neral and geranial, which are responsible for lemon odour. Their proportion is $3: 4$, and the presence of 6-methyl-5-hepten-2-one and $\beta$-caryophyllene are the criteria of identification of lemon balm oil. The second group of the substances of lemon balm are phenylpropanoids, including rosmarinic acid as the most distinctive ones (Noguchi-Shinohara et al., 2015). Phenylpropanoids are also represented by ethyl oil of rosmarinic acid, caffeic acid, chlogenic acid, para-coumaric acid, ferulic acid and sinapinic acid. Using the method of liquid chromatography, we determined that content of rosmarinic acid in the leaves of lemon balm accounts for $0.54-1.79 \%$. Among the phenol substances, antioxidant activity was exhibited by flavonoids apigenin, cosmosiin, luteolin, cynaroside, and also ramno-citrin (7-metoxy kaempferol) and iso- quercetin (3- quercetin glucoside), rhamnazin (3,7 dimetoxycampheroll). Moreover, the plant contains phenolcarbonic acids: gentisic, salicylic, p-hydroxybenzoic, vanillic, syringic, protocatechuic acids, and also tannins and coumarins. Out of sterols, the plant was observed to have daucosterol, out of saponins - ursolic acid. Broad spectrum of therapeutic effect of the plant-based preparations is related to the content of various substances: sedative effect was described for citronellal, and spasmolytic - for geraniol and citronellol. Phenylpropanoids (rosmarinic, caffeic, chlorogenic and other hydroxycinnamic acids) are responsible for anti-viral, immune-modulling, antihistamine, antioxidant and antimicrobial properties (Bounihi et al., 2013; Seol et al., 2013; Joukar et al., 2014; Joukar \& Asadipour, 2015; Hamza et al., 2016; Jeung et al., 2016; Safaeian et al., 2016; Shakeri et al., 2016; Sedighi et al., 2019). Furthermore, the plant has for a long time been broadly used as sedative preparation and so as to optimize the irritation of the nervous system (Bayat et al., 2012; de Cássiada Silveirae Sá et al., 2013; FeliúHemmelmann et al., 2013; Akbarzadeh et al., 2015; Ozarowski et al., 2016; Naderi Dastjerdi et al., 2019). There are reports about antihyperglicemia effect of Melissa essential oil in laboratory experiment (Hasanein \& Riahi, 2015), positive effect from regulation of visceral adipose-tissue function in the conditions of nonalcoholic fatty liver diseases caused by high-fat diet (Kim et al., 2017). Park et al. (2015) indicate that angiogenesis inhibitor ALS-L1023 of M. officinalis helps to decrease the adipose tissue mass. Melissa speeds up the rates of restoration of traumas of the spinal marrow (Hosseini, 2020). Traditional Persian Medicine recommends rosmarinic acid-containing lemon balm as a dietary component for improving memory, treating cognitive disorders and, due to its antiamyloidogenic and other properties, for consumption when having Alzheimer's disease (Iranshahy \& Javadi, 2019). Its flavour is generated by geraniol (3-40\%), neral (3-35\%), geranial (4-85\%), (E)-caryophyllene
(0-14\%), and citronellal (1-44\%) (Setzer, 2009). Lemon balm has been traditionally used as tonic, antispasmodic, carminative, diaphoretic, surgical dressing for wounds, sedative-hypnotic preparation that strengthens the memory, and relieves of stress-induced headaches, though modern pharmacology evalueates its efficacy against mild to moderate Alzheimer's diseases, migraines and rheumatism, antitumel and antioxidant activities (Moradkhani et al., 2010).

M. officinalis is widely used not only in the traditional medicine of the Old World, but in the folk medicine of the Americas as well. For instance, in the state of Rio Grande do Sul (South Brazil), this plant is used (Gross et al., 2019) against symptoms related to the central nervous system (M. officinalis was included in $77.7 \%$ of ethnobotanical that cited 94 species of plants). Records of practices involving $M$. officinalis in traditional medicine are reported mostly for European countries, Mediterranean region and Middle East countries (Shakeri et al., 2016).

Lemon balm is third plant according to the content of antioxidants out of 57 species of spicy and medicinal plants used in the experiment (Sammar et al., 2019). Citral it contains is able to efficiently inhibit cancer cells and induce cell apoptosis (Bailly, 2020). Its complex anticancer mechanism involves three actions: (I) the preparation leads to accumulation of reactive oxygen types in cancer cells, thus entailing an oxidative burst and damage to DNA, (II) a colchicine-like inhibition of tubulin polymerization and promotion of microtubule depolymerization, associated with inhibition of the microtubule affinity-regulating kinase MARK4, and (III) a potent inhibition of aldehyde dehydrogenase isoform ALDH1A3, related to cancer stem cell proliferation and chemoresistance (Bailly, 2020). Unfortuanately, the citral's potential is limited, mostly due to insufficient stability of the drug and its low bioavailability, and low selectivity for cancer cells against non-tumour cells. Nonetheless, citral is promising for development of effective analogues and drug combinations having a reinforced potential to treat tumours (Bailly, 2020).

Rosmarinic acid, present in many plants of Laminiaceae family, is broadly used as culinary herbs: Ocimum basilicum L. (basil), Ocimum tenuiflorum L. (holy basil), M. officinalis L. (lemon balm), Salvia rosmarinus Spenn. (rosemary), Origanum majorana L. (marjoram), Salvia officinalis L. (sage), Thymus vulgaris L. (thyme) and Mentha $\times$ piperita L. (peppermint) (Clifford, 1999; Sik et al., 2019). Rosmarinic acid is a secondary metabolite of plants, which they synthesize to protect themselves against fungi and bacteria, as well as herbivorous organisms. Plant contains rosmarinic acid in the vacuoles, separately from oxidase enzymes. In case of plant's trauma, oxidases influence the rosmarinic acid, and the phenol hydroxyl group of rosmarinic acid become oxidized to orto-chinons. They bind with proteins of bacteria, fungi or herbivorous animal, thus inactivating them (Häusler et al., 1993). Rosmarinic acid of Lamiaceae plants exerted inhibition of chlorine esterase, and was reported to be effective in dementia intervention. Shinjyo \& Green (2017) reviewed the reports on efficiency of these herbs, finding seven out of eight articles on lemon balm indicating its positive effects on mood and cognition, while one study observed no effect (Shinjyo \& Green, 2017). The summary by Shakeri et al. (2016) describes the botanical characterization, traditional uses, phytochemistry, pharmacological activities, pharmacokinetics and toxicity of M. officinalis, and discusses blanks in the data and perspectives of surveying this plant.

M. officinalis and its major constituent - rosmarinic acid - exhibit powerful antioxidant and anti-inflammatory activities. Likewise, studies demonstrated that $M$. officinalis and rosmarinic acid mitigates the effects of memory loss caused by Alzheimer's disease (Eivani \& Khosronezhad, 2020). Rosmarinic acid is considered to be metabolized by gut microbiota, thus providing phenolic elements that may be absorbed more easily. In the human organism, molecules of rosmarinic acid alter their structure, undergo conjugation reactions, and are removed with excrements (Hitl et al., 2021).

Lavandula angustifolia Mill. is a perennial shrub of Lamiaceae family. Height of cultivated plants reaches $100-200 \mathrm{~cm}$, and the plants in the nature grow up to $50-70 \mathrm{~cm}$. The leaves are opposite, elongated-linear, with bent margins, $2-6 \mathrm{~cm}$ in length, grey-green from the indumentum. All the parts of the plant contain essential oil: leaves - up to $0.4 \%$, the stems - to $0.2 \%$, inflorescences $-3.5-4.5 \%$. The main constituents of the essential oil (30-60\%) are complex ethers of L-linalool alcohol and acids (acetic, butyric, valeric, and caproic acids). Furthermore, it was found to 
contain cineol, geraniol, borneol (Karabagias et al., 2019). The gas chromatography revealed the shares of the main components to equal as follows: linalyl acetate $(25-46 \%)$, linalool $(20-45 \%)$, terpinen-4-ol $(1.2$ $6.0 \%)$, lavendulyl acetate $(>1.0 \%), 1,8$-cineole $(<2.5 \%), 3$-octanone $(<2.5 \%)$, camphor $(<1.2 \%)$, limonene $(<1.0 \%)$, and alpha-terpineol $(<2.0 \%)$ (Koriem, 2021). Flowers and oil of lavender are used as a culinary spice. It is particularly popular in Spanish, French and Italian cuisines. Sedative effect of lavender during neurasthenia and heightened pulse is achieved through baths. It is also used in dental practice for inhalation treatment of rhinites, laryngitis; it is applied to speed up the wound healing after surgeries (Wang et al., 2012; Yu \& Seol, 2017; Mekonnen et al., 2019). Lavender oil is used to improve the odor of medicines. In folk medicine, the alcohol solutions of oil of lavender and inflorescence are applied to treat migranes, neurasthenia, stress (Kennedy \& Wightman, 2011; Lundstrom et al., 2017; Uritu et al., 2018), rheumatism, heartvascular diseases, kidney-stone disease and pyelonephritis, for medical baths during joint inflammation, for would-healing, durig skin diseases and neuralgias, bruises and paralyses (Ziaee et al., 2015; Sadeghzadeh et al., 2017; Samarth et al., 2017; Xu et al., 2017; Cardia et al., 2018; Boukhatem et al., 2020). In households, the flowers of lavender are used to scare off mosquitoes, blackflies and no-see-ums, and protect fur goods against moths. Similarly to other species of Laminiaceae family, lavender is a good nectar-bearer whose honey is considered healing. Lavender hybrids are called lavandins. Hybrids between $L$. angustifolia and $L$. latifolia (spike lavender) are called Lavandula $\times$ intermedia. They bloom later than the common English lavenders. Based on lavender, complex medicinal nano particle-containing preparations are developed (Shokri et al., 2017; Belova et al., 2019).

For centuries, the most commonly used species of Lavandula genus have been $L$. angustifolia, $L$. latifolia, $L$. stoechas and $L . \times$ intermedia (Cavanagh \& Wilkinson, 2002; Woronuk et al., 2011). Despite the research data on this subject oftentimes being inconclusive and controversial, the benefits of lavender have nonetheless been confirmed by a number of studies (Cavanagh \& Wilkinson, 2002). The surveys mainly focused on its effect on pain, anxiety, learning, memory, attention, arousal, relaxation, sedation and sleep (Dobetsberger \& Buchbauer, 2011). Constituents of lavender essential oil have immune-moduling activity, increase phagocytic activity of macrophages toward the bacteria (Peterfalvi et al., 2019). Likewise, it is being considered for treatment of epilepsy, stress, dementia and Alzheimer's disease (Dobetsberger \& Buchbauer, 2011; Oskouie et al., 2018). Essential oils from L. angustifolia improved cognitive performance and took positive effects on animals and humans suffering neurodegenerative disorders such as Alzheimer disease and dementia (Ayaz et al., 2017). Also, this oil was reported to have neuroprotective effects (Ayaz et al., 2017). Lavender and lavandin essential oils prepared by stem distillation are usually composed of terpenes (e.g. linalool and linalyl acetate) and terpenoids (e.g. 1,8-cineole), responsible for their distinctive flavour and biological and therapeutic properties (Lesage-Meessen et al., 2015). Extract from $L$. angustifolia exhibited positive influence of motor dysfunction on the model of SCI bruise and contributed to the morphological improvement, having therapeutic potential for treatment of spinal cord damage (Kaka et al., 2019). Traditional medical practices all around the globe prescribe essential oils to treat a number of health issues (Raut \&Karuppayil, 2014). The study by Todorov et al. (2014) discussed phytochemical composition of the essential oil concerning the influence on particular stages of viral life. The composition of the essential oil of the plant varies depending on various climates, as well as light, nutrients, temperature, and cultural practice genotype and oter factors. Nonethless, the major components are always citral (geranial and neral), citronellal, geraniol (Moradkhani et al., 2010).

Herbal essential oils are being more and more often used in pharmacology, medicine and food processing (Greff et al., 2020). Lemon balm and lavender are among the top ten most broadly applied medicinal and aromatic plants (Greff et al., 2020). Well-substantiated is the woundhealing property of essential oil of lavender (Samuelson et al., 2020). It significantly enhanced would healing and heightened the expression level of collagen, as well as activity of proteins taking part in tissue remodeling in wounds (Samuelson et al., 2020). Through studies of essential oil, it is possible to identify new bioactive compounds and find formu- lae of new preparations to treat cardiovascular diseases such as arterial hypertension, angina pectoris, heart failure, and myocardial infarction (Saljoughian et al., 2018). Over the recent five years, in the USA, health care-expenses related to cardiovascular diseases have increased $50 \%$, accounting for 350 billion dollars (Bojic et al., 2019). In the recent decade, the number of research on antiaggregatory effect of polyphenol increased two-fold. Bojic et al. (2019) reviewed the antiaggregatory effects of most abundant polyphenols and flavonoids and plyphenols-rich plants (for example $L$. angustifolia and $M$. officinalis) on platelet aggregation, association of chemical composition and antioxidant properties with the observed biological effect, and possible clinical significance of the results they published. Cardiovascular diseases are among the most damaging health issues nowadays. Strokes and heart attacks often cause death, and another threat is posed by development of thrombus. Therefore, the therapy pays great attention to the level of primary hemostasis, first of all the clot formation, using acetylsalicyc acid and clopidogrel treatment. Use of plants rich in polyphenols to prevent thrombus development is relevant, as indicated by the two-fold increase in research on this issue over the last decade (Bojic et al., 2019).

Vitex agnus-castus L. is a tree-like shrub of the Lamiaceae family of up to $800 \mathrm{~cm}$ height. The plant is grey from pubulent dense adjascent hairs with distinctive aroma. The leaves are large, opposite, palmate, on long petioles. Has numerous blue flowers. Its range comprises North Africa, Southern Europe, West Asia, Transcaucasia, and Central Asia (Artz, 2007; Brown \& Murray, 2012). It has been cultivated in gardens as an ornamental plant since the Middle Ages. The medicinal raw material is leaves, flowers, fruits, branches, and more rarely bark (Ross, 2001). All the parts of the plant contain iridoidglycoside (agnuside, aucubin), flavonoids (casticin, vitexin, isovitaxin, orientin, isoorientin), p-hydroxybenzoicacid, alkaloids, tannins, essential oil (Stojković etal., 2011). The essential oil from leaves contains 1,8-cineole, trans-beta-farnesene, alphapinene, trans-beta-caryophyllene, andterpinen-4-ol. The oil from leaves of $V$. agnus-castus contains 46 compounds. The major constituents of the leaves are 1,8-cineole $(22.0 \%)$, trans-beta-farnesene (9.4\%), alpha-pinene (9.4\%), trans-beta-caryophyllene (8.2\%), terpinen-4-ol (7.8\%), limonene (4.8\%), alpha-terpineol (3.8\%), sclarene (3.3\%), alpha-terpinyl acetate (3.1\%), p-cymene (3.0\%) (Stojković et al., 2011). 1,8-cineole and alphapinene exerted notable antimicrobial potency as well (Stojković et al., 2011). The oil, particularly such from white flowering plants, is surveyed for its potential antibacterial effects (Stojković et al., 2011). Extract from V. agnus-castus exhibited the greatest cytotoxic activity out of 57 medicinal plants tested in the experiment (Sammar et al., 2019). The authors also indicate that powerful cytotoxicity is not related to low concentrations of antioxydants in it, but manifests through other signal pathways. The ripe fruit of $V$. angus-castus could be a promising anticancer agent (Kikuchi et al., 2014). Vitex was observed to induce dose- and timedependent decrease in cell viability following the induction of apoptosis and $\mathrm{G}(2) / \mathrm{M}$ cell cycle arrest. Clinical applications of Vitex revealed new data on interaction of Vitex with other conventional drugs able to affect intracellular redox status (Kikuchi et al., 2014). Alpha,beta-unsaturated gamma-lactam moiety, 9 alpha-hydroxy-13(14)-labden-16,15-amide (1), together with five known ones, were isolated from the fruits of $V$. anguscastus (Pal et al., 2013).

Fruits and herbs of $V$. agnus-castus are included in the European pharmacopoeia. The plant is used during insufficient lactation, menstrual period problems, and also as diuretic and irritating preparation. The leaves are added to meat meals, soups, jam and half-smoked sausage, canned fish. During food preservation, vitex is used as a substitute of allspice. In men's bodybuilding, it is used to control testosterone level. Vitex-based preparations are used in gynecology during premenstrual syndrome accompanied by edemas, poor bleedings or absence of them, anovulatory cycles, period disorders after using birth control preparations, infertility related to hyperprolactinaemia, breast pains (Arzi et al., 2019). For this purpose, the plant is processed to prepare cyclodynon, mastodynon, pregnatone, prefemin, biocycline, and others. Vitex is traditionally recommended medicine against premenstrual stress syndrome, premenstrual dysphoric disorder and other reproductive health issues in women. Nonetheless, despite the fact that it is often recommended in Germany, there are some indications that $V$. agnus-castus may lead to complications during 
pregnancy. In the studies by Maleki-Saghooni et al. (2018), V. agnus-castus and $M$. officinalis mitigated symptoms of premenstrual syndrome (PMS).

Safarabadi et al. (2018) consider $L$. officinalis and $V$. agnus-castus some of the most important analgesic plants. The research notes that the herbs have anti-nociceptive effects, inhibition of the release of arachidonic acid, synthesis of prostaglandins and action toward the opioid system, with peripheral anti-nociceptive mechanism and cholinergic pathways, stimulation of GABA A receptors, COX-1 and 5- $\mathrm{LO}$ and central and environmental mechanisms (Safarabadi et al., 2018).

Nonetheless, topically applied herbal medicinal preparations made of L. angustifolia may lead to such side-effects as contact dermatitis (Gangemi et al., 2015). Biological properties of linalool, namely sedative, anxiolytic, analgesic, anticonvulsant, anti-inflammatory, local anaesthetic, are discussed in the context of the molecule's chirality influence, the mechanisms of activity and type of study (in vitro, in vivo, clinical studies) (Aprotosoaie et al., 2014). The recently obtained data on properties of linalool to skin synthesis are considered in report by Aprotosoaie et al. (2014).

Despite the relatively thorough degree of study of the chemical composition and application of those plants during separate human and animal diseases (Wynn \& Fougère, 2007; Lee et al., 2014; Zarei et al., 2014; Kubo et al., 2015; Saberi et al., 2016; Dolatabadi et al., 2018; EFSA Panel et al., 2020; Torki et al., 2021), no complex impact of these three species of medicinal plants during high-fat diet and excessive consumption of food was found. Therefore, the objectives of this study were overall effects of M. officinalis, L. angusti folia, $V$. agnus-castus on weight gain, changes in index of body weight, biochemical and morphological blood parameters, orienting-motor activity and emotional status of white laboratory rats against the background of excessive fat diet.

\section{Materials and methods}

Selection of animals for the experiment, the study protocols, euthanasia of animals were approved by the local ethics committee of the Dnipro State Agrarian-Economical University. Content, feeding, care for the animals and withdrawal of the animals from the experiment were performed following the principles formulated in the European Convention for the Protection of Vertebrate Animals used for Experimental and Other Scientific Purposes (Strasburg, March 18, 1986, ETS No. 123) and the order No. 3447-IV as of 21.02.2006 "On protection of animals against abuse" (Ukraine).

In the experiment, we used 32 adult white outbred laboratory male rats of $200 \pm 10 \mathrm{~g}$ weight. The rats were divided into the control and experimental groups with 8 animals in each. The rats were kept in polycarbonate cells with steel grid covers, food pit, 4 individuals per a cell. The rats were maintained in the room with the temperature of $20-22^{\circ} \mathrm{C}$ and relative air moisture of $50-65 \%$. Light regime was $12 \mathrm{~h}$ of light and $12 \mathrm{~h}$ of dark. The ventilations were performed according to the regime. The animals received water ad libitum.

The diet of all animals had excessive fat content $(3,600 \mathrm{ccal} / \mathrm{kg})$ High-fat diet was composed based on the standard diet ( $75 \%$ of grain mixture (maize, sunflower seeds, wheat, barley), $8 \%$ of root vegetables (potatos, carrot), $2 \%$ of meat and bone meal, $2 \%$ of mineral-vitamin complex) with introduction of $15 \%$ of sunflower oil. The control group of animals received high-fat diet, while the experimental group was fed with high-fat diet supplemented with the medicinal plants. The first experimental group, in addition to high-fat diet, was given 5\% dry crumbled young shoots of $L$. angustifolia; the second experiment $-5 \%$ M. officinalis; the third experimental $-5 \% \mathrm{~V}$. agnus-castus. The main ingredients of the diet were crushed in the mill (grain, meat and bone meal, mineral-vitamin complex, dry shoots of medicinal plants) and mixed. Then we have added sunflower oil, and prepared granules assessing the amount equaling 4,200 $\mathrm{g}$ for each group for the whole period of the experiment (30 days). Fresh root vegetables in the corresponding amount were given additionally daily. The animals had free access to the food. During the experiment, we recorded the amount of food consumed by each group a day and its total amount thoughout the experiment.

Morphometric parameters (live mass, belly volume) were determined on the first and the 30th days of the experiment (Lieshchova et al., 2018, 2019, 2020). The calculated parameters were the overall increase in live mass and daily weight gains.

Orienting-motor activity and emotional status of the organisms of the experimental animals were studied in the "open field" test using an installation of $1 \mathrm{~m}^{2}$ square area divided into 16 squares and limited nontransparent $20 \mathrm{~cm}$-heigh wall. The experiment was performed in complete silence with intense light on the field itself. An experimental animals had been taken from the cage from previously shadowed compartment and placed in the center of the field. The exposure time was 2 min. The animals were tested for 4 days (1-4th days) at the beginning of the experiment and 4 days at the end (26-30th). We counted the number of squares the animals passed: peripheral and central ones - we assessed moving activity; peripheral (with reliance on the wall) and central (without reliance on the wall) stances - orienting activity; the amount of acts of grooming, defecation and urination - emotional status (Fig. 1).

The animals were euthanized on the 30th day of the experiment under narcosis $(80 \mathrm{mg} / \mathrm{kg}$ of cetamine and $12 \mathrm{mg} / \mathrm{kg}$ of xylazine, intraperitoneal injection) by cardiac exsanguination. After the autopsy, we visually assessed the condition of the internal organs on the presence of pathological changes. The extraction of the organs and the tissues (heart, liver, lungs, thymus, spleen, stomach, thin and large intestines, kidneys) was carried out using surgical tools. The weight of the internal organs was determined with the accuracy of $\pm 0.01 \mathrm{~g}$.
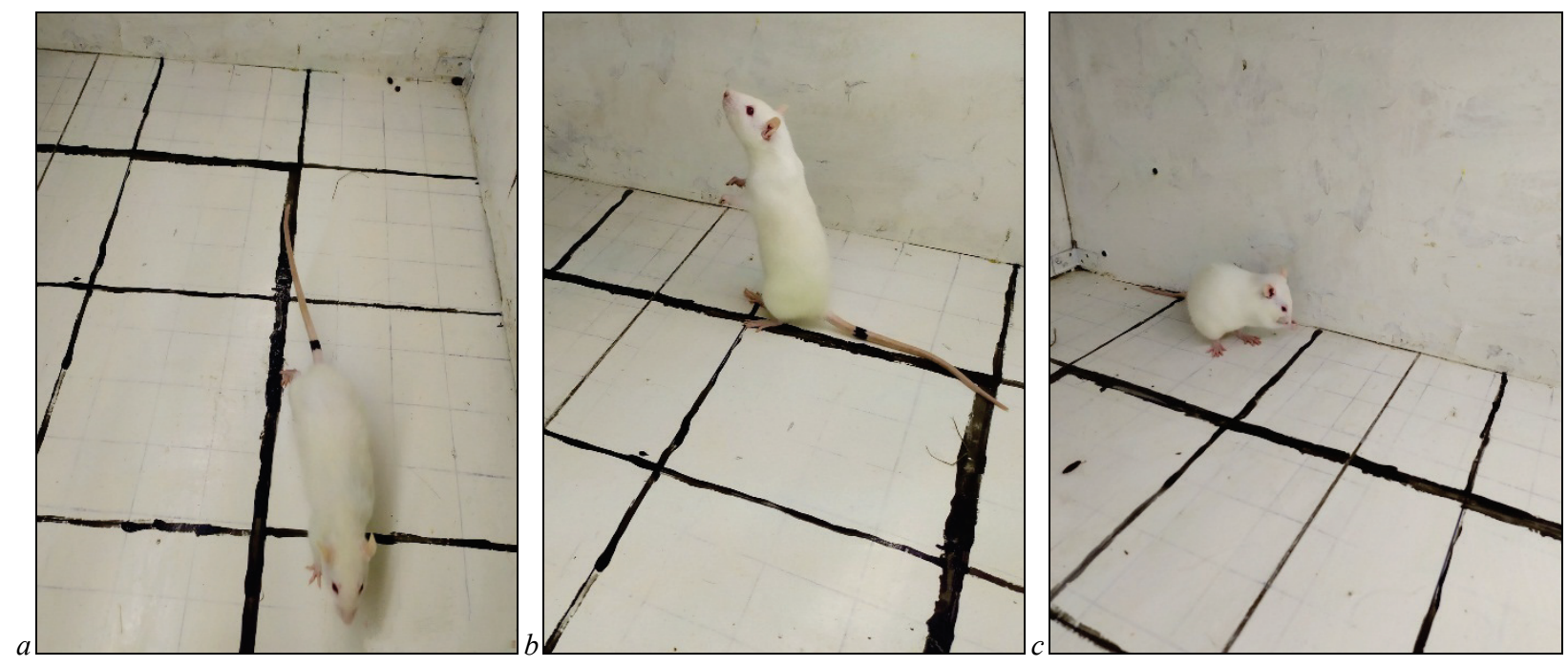

Fig. 1. Behaviour of rats in the "open field" test: $a$-crossing of peripheral squares, $b$-central stance, $c$-act of grooming 
Blood samples taken during te euthanasia were then used for biochemical and morphological assays. Biochemical parameters were determined using Miura automated analyzer (I.S.E. Srl, Italy) and a set of HighTechnology reagents (USA), PZCormay S.A. (Poland) и Spinreact S.A. (Spain). The erythrocytes and leukocytes in stabilized blood were counted using automated BC-2800Vet analyzer (Mindray, China).For the leukogam, we prepared blood smears according to Pappenheim with subsequent Romanovsky-Giemsa staining. The numbers of erythrocytes and leukocytes in stabilized blood of mice were determined using automatic haematological analyzer BC-2800Vet and Mindray (Lieshchova et al., 2018, 2019, 2020; Brygadyrenko et al., 2019).

The data were analyzed using Statistica 8.0 program (StatSoft Inc., USA). The tables demonstrate the results as $\mathrm{x} \pm \mathrm{SD}$ (standard deviation). Differences between the values of the control and experimental groups were determined using the Tukey test, where the differences were considered significant at $\mathrm{P}<0.05$.

\section{Results}

The median of the body weight on the 11th day increased to $110.2 \%$ compared with the initial weight in the control group of animals (Fig. 2a). By the end of the experiment (by the 30th days), the body weight did not exceed $112.0 \%$ of the initial weight. Stems of $L$. angustifolia caused almost even gain in body weight of the animals to $139.2 \%$ by the 30 th days as compared with the initial weight for this group. Male rats that consumed shoots of $M$. officinalis, to the 30th days of the experiment, had the weight of $134.5 \%$ of their individual initial weight (Fig. 2b). Shoots of $V$. angus-castus caused slower weight gain than lavender and lemon balmto $118.8 \%$ of the body weight at the beginning of the experiment (Fig. 2c).

Shoots of $L$. angustifolia and $M$. officinalis significantly decreased the food intake to $83.0 \%$ and $84.1 \%$ compared with the control respectively (Table 1). Water intake in the experimental groups was no different from the control.

At the same time, adding shoots of $L$. angustifolia and M. officinalis caused reliable (more than 2.5-fold) increase in the mean daily body weight gain (Table 1): instead of $700 \mathrm{mg} /$ day, the animals gained 1,943 and $2,024 \mathrm{mg} /$ day, respectively. Herbs of $V$. angus-castus led to less notable and statistically insignificant increase (up to $138.1 \%$ of the control Table 1

Change in the body weight and food consumption of young male rats under the impact of addition of crumbled shoots of Lavandula angustifolia Mill., Melissa officinalis L. and Vitex angus-castus L. to their $\operatorname{diet}(\mathrm{x} \pm \mathrm{SD}, \mathrm{n}=8$, duration of experiment -30 days)

\begin{tabular}{|c|c|c|c|c|c|c|c|}
\hline Parameter & Control & L. angustifolia & $\begin{array}{l}\text { L. angustifolia } \\
\text { compared to the } \\
\text { control, } \%\end{array}$ & M. officinalis & $\begin{array}{l}\text { M. officinalis } \\
\text { compared to the } \\
\text { control, } \%\end{array}$ & V. angus-castus & $\begin{array}{l}V \text {. angus-castus } \\
\text { compared to the } \\
\text { control, } \%\end{array}$ \\
\hline $\begin{array}{l}\text { Consumption of food } \\
\text { by animals, g/day }\end{array}$ & 20.09 & 16.67 & 83.0 & 16.90 & 84.1 & 18.81 & 93.6 \\
\hline $\begin{array}{l}\text { Consumption of liquid } \\
\text { by animals, g/day }\end{array}$ & 18.42 & 18.50 & 100.5 & 19.05 & 103.4 & 18.93 & 102.8 \\
\hline Change in body weight, $\mu \mathrm{g} /$ day & $700 \pm 271$ & $1943 \pm 496^{* * *}$ & 277.6 & $2024 \pm 393 * * *$ & 289.1 & $1171 \pm 417$ & 167.3 \\
\hline Change in body weight, $\% /$ day & $13.6 \pm 5.9$ & $35.7 \pm 8.0 * * *$ & 261.7 & $36.7 \pm 7.9^{* * *}$ & 269.3 & $18.8 \pm 6.5$ & 138.1 \\
\hline Объем живота, см & $14.0 \pm 0.5$ & $14.0 \pm 0.9$ & 99.9 & $13.8 \pm 0.4$ & 98.9 & $14.8 \pm 1.0$ & 106.0 \\
\hline
\end{tabular}

Note: ${ }_{-}^{*} \mathrm{P}<0.05,{ }^{* *}-\mathrm{P}<0.01,{ }^{* *}-\mathrm{P}<0.001$, significant differences within one line of the table according to the results of ANOVA with Bonferroni correction.

Table 2

Changes in relative mass of the organs (\%) of male rats under the influence of addition of crumbled shoots of Lavandula angustifolia Mill., Melissa officinalis $\mathrm{L}$. and Vitex angus-castus $\mathrm{L}$. to their $\operatorname{diet}(\mathrm{x} \pm \mathrm{SD}, \mathrm{n}=8$, duration of experiment -30 days)

\begin{tabular}{|c|c|c|c|c|c|c|c|}
\hline Organ & Control & L. angustifolia & $\begin{array}{l}\text { L. angustifolia } \text { com- } \\
\text { pared to the control, } \%\end{array}$ & M. officinalis & $\begin{array}{l}\text { M. officinalis compared } \\
\text { to the control, } \%\end{array}$ & $\begin{array}{l}\text { V. angus- } \\
\text { castus }\end{array}$ & $\begin{array}{l}V . \text { angus-castus com- } \\
\text { pared to the control, } \%\end{array}$ \\
\hline Heart & $0.352 \pm 0.023$ & $0.362 \pm 0.036$ & 103.0 & $0.330 \pm 0.025$ & 93.7 & $0.352 \pm 0.033$ & 100.2 \\
\hline Liver & $4.08 \pm 0.17$ & $4.32 \pm 0.36$ & 105.8 & $3.87 \pm 0.36$ & 94.8 & $3.71 \pm 0.26$ & 91.0 \\
\hline Lungs & $0.979 \pm 0.169$ & $0.880 \pm 0.190$ & 89.9 & $0.872 \pm 0.138$ & 89.2 & $0.967 \pm 0.365$ & 98.8 \\
\hline Brain & $0.867 \pm 0.052$ & $0.700 \pm 0.073^{* * *}$ & 80.8 & $0.738 \pm 0.075^{*}$ & 85.2 & $0.698 \pm 0.142$ & 80.5 \\
\hline Thymus & $0.285 \pm 0.046$ & $0.166 \pm 0.077^{* *}$ & 58.3 & $0.133 \pm 0.040^{* * *}$ & 46.7 & $0.221 \pm 0.043$ & 77.6 \\
\hline Spleen & $0.370 \pm 0.036$ & $0.473 \pm 0.159$ & 128.0 & $0.412 \pm 0.150$ & 111.5 & $0.470 \pm 0.070^{*}$ & 127.0 \\
\hline Stomach & $0.699 \pm 0.060$ & $0.769 \pm 0.211$ & 110.0 & $0.764 \pm 0.206$ & 109.4 & $0.847 \pm 0.266$ & 121.3 \\
\hline Small intestine & $2.58 \pm 0.52$ & $2.16 \pm 0.25$ & 83.8 & $2.20 \pm 0.25$ & 85.0 & $2.44 \pm 0.32$ & 94.7 \\
\hline Cecum & $0.509 \pm 0.176$ & $0.457 \pm 0.099$ & 89.9 & $0.422 \pm 0.077$ & 82.9 & $0.509 \pm 0.262$ & 100.1 \\
\hline Large intestine & $0.374 \pm 0.085$ & $0.397 \pm 0.121$ & 106.2 & $0.400 \pm 0.082$ & 107.0 & $0.431 \pm 0.089$ & 115.4 \\
\hline Rectum & $0.398 \pm 0.073$ & $0.307 \pm 0.077$ & 77.2 & $0.203 \pm 0.104^{* *}$ & 51.0 & $0.366 \pm 0.063$ & 92.0 \\
\hline Right kidney & $0.358 \pm 0.031$ & $0.321 \pm 0.027$ & 89.6 & $0.317 \pm 0.031$ & 88.4 & $0.310 \pm 0.026$ & 86.4 \\
\hline Left kidney & $0.372 \pm 0.040$ & $0.319 \pm 0.022$ & 85.7 & $0.321 \pm 0.039$ & 86.4 & $0.308 \pm 0.030$ & 82.8 \\
\hline
\end{tabular}

Note: see Table 1. group) in daily body weight increment of the animals compared with the sed by the three tested species of plants. Under the influence of addiof the shoots of $L$. angustifolia and M. officinalis to the diet, we seen (he rats. When consignificantly decreased (to $58.3 \%$ and $46.7 \%$ of the relative mass of the thymus in animals of the control group, respectively). Intake of the shoots of $V$. angus-castus led to statistically significant increase in the relative (Table 2). , which manifested in almost two-fold elevation of the level of was in the norm. Also, consumption of large amount of fat caused increase in the glucose level, whereas during addition of medicinal plants to the diet, this parameter remained within the values of the norm. Activity of refence values, indicating somewhat damage to hepatocytes, while the (ne absolute weight of the organ, absence of macroscopic signs protein) were within the norm

Intake of lavender shoots stimulated notable increase in alkaline phosphatase (to $349.7 \%$ of the levels of the control group), concentration LDL cholesterol (to $227.7 \%$ ) and moderate significant increase in the Consumption of crumbled shoots of lemon balm caused great increase in 列 zyme in the control group), decrease in the concentration of urea nitrogen (to $79.0 \%$ ), total bilirubin (to $63.3 \%$ ) and triglycerides (to $63.1 \%$ ) in blood ing ince phosp(to $406.2 \%$ of the control group), index of aterogenecity (to $524.0 \%$ of the control group) first of all due to decrease in the concentration of HDL cholesterol (to $51.9 \%$ of the control group). Also, there was seen decreases in the concentration of triglycerides (to $56.4 \%$ of the control group) and glucose (to $80.9 \%$ of the control group, Table 3 ). 


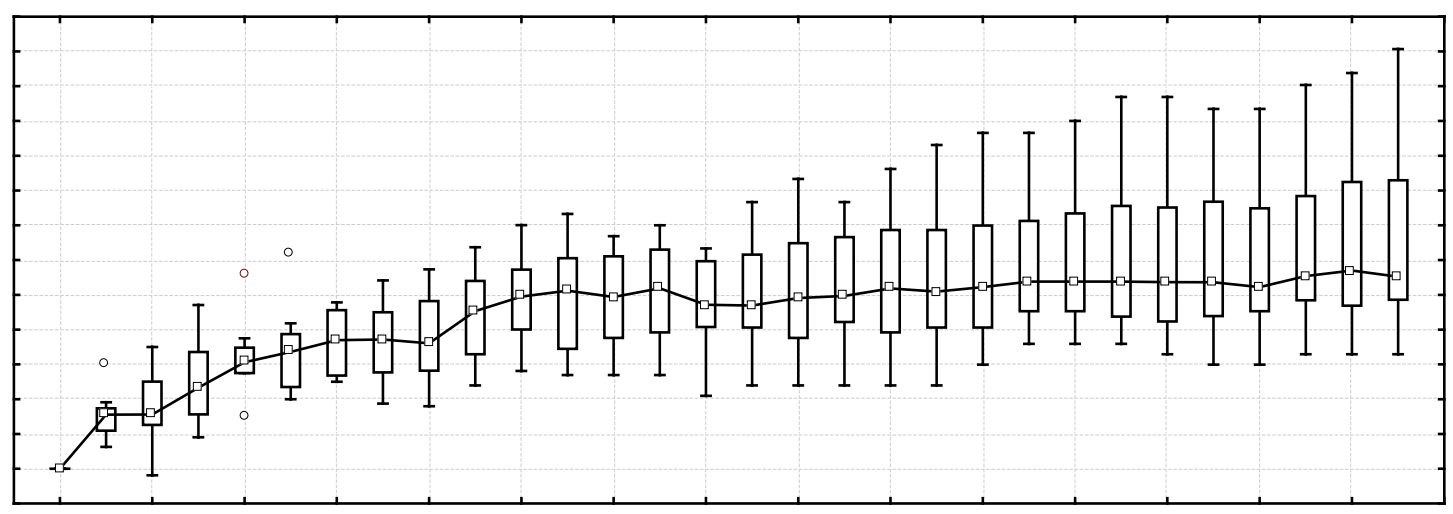

$a$

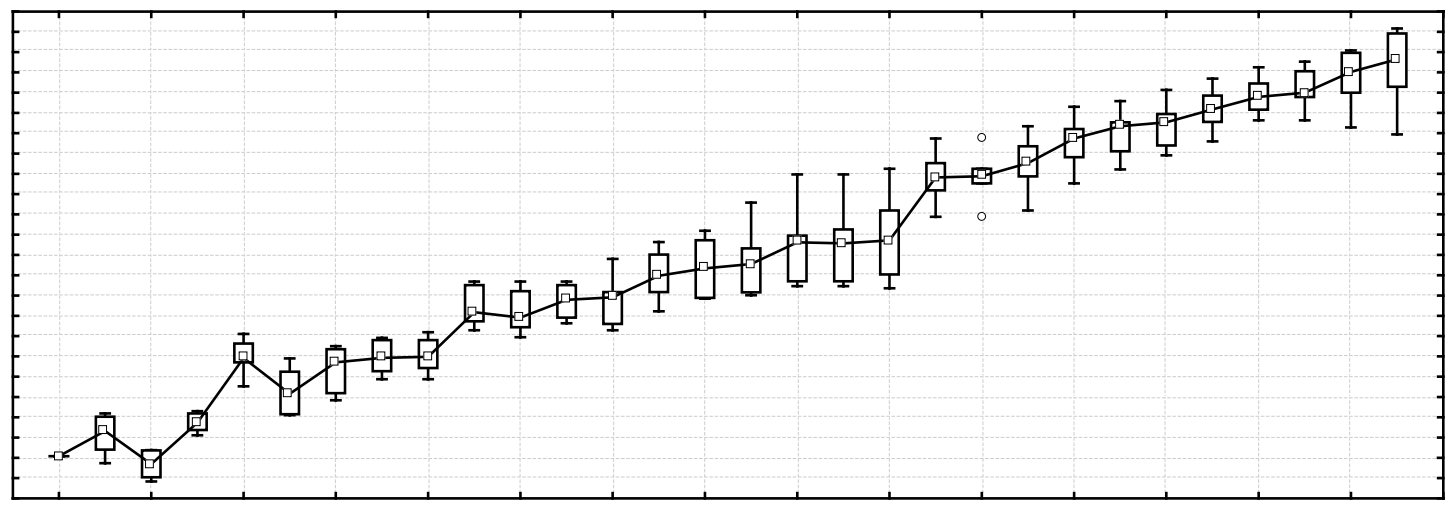

$b$

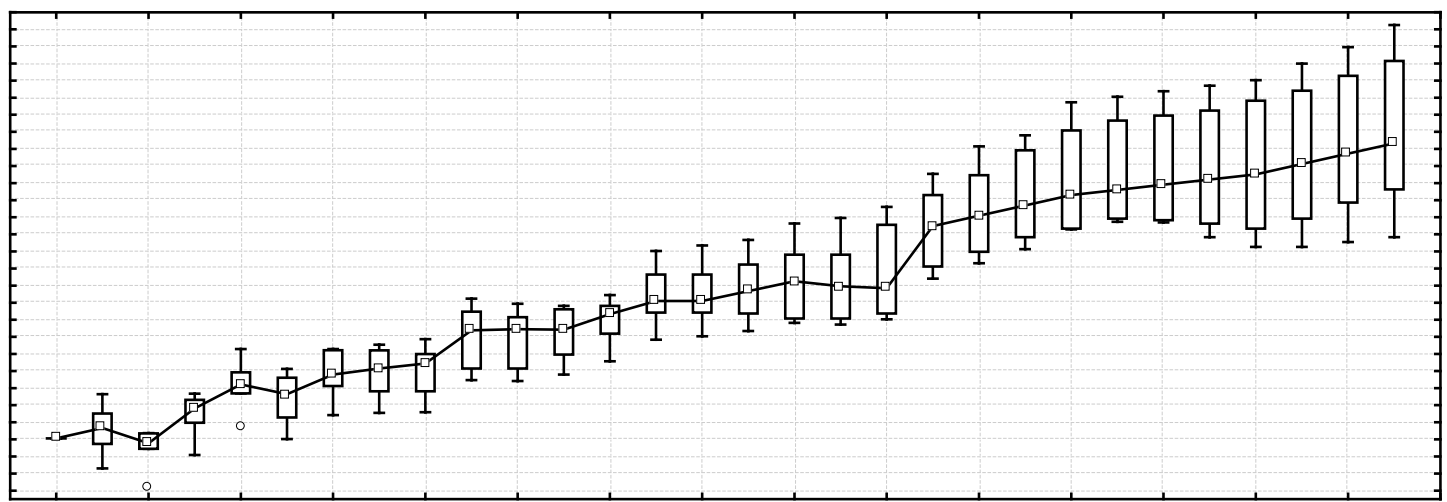

$c$

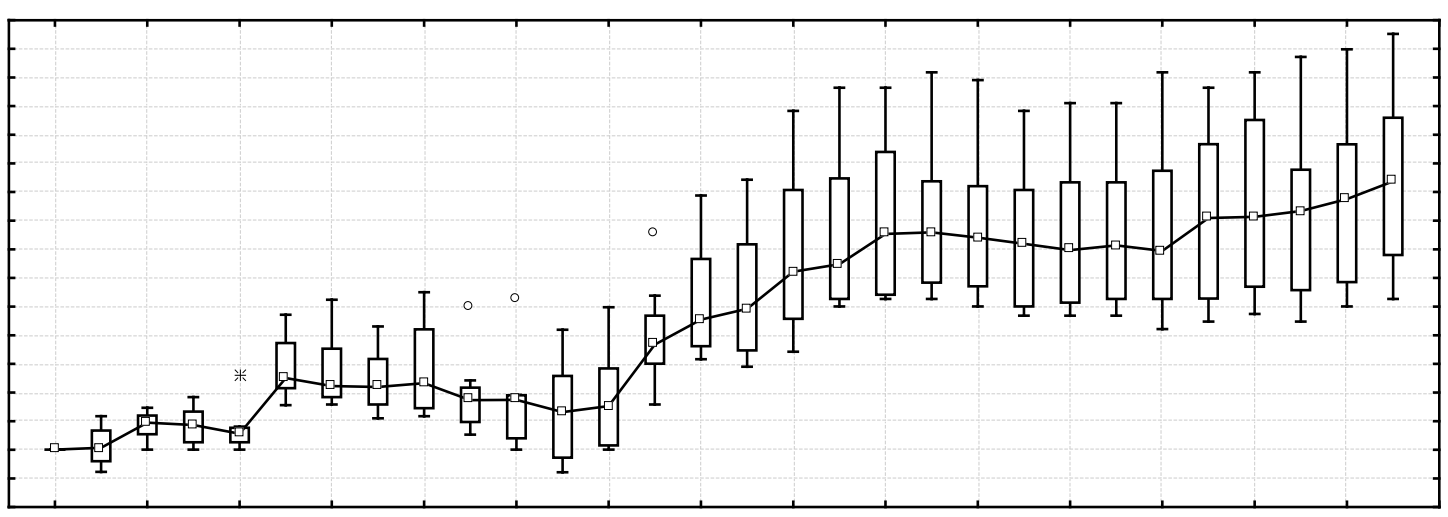

$d$

Fig. 2. Changes in the body weight of the rats in the control variant of the experiment (a) and when adding grined seeds of Lavandula angustifolia Mill. (b), Melissa officinalis L. (c) and Vitex angus-castus L. (d) into the diet: on the abscissa axis - $24 \mathrm{~h}$ of the experiment, on the ordinate axis - body weight of the animals ( $\%$ of the initial wody weight before the experiment, considered $100 \%$ for each experimental animal); small square - median, upper and lower borders of the square $-75 \%$ and $25 \%$ of quartiles, the upper line - minimum and maximum values, circles - emissions; $n=8$ 
Analysis of protein metabolism revealed that high-fat diet did not increase the concentration of the total protein. Addition of vitex and lemon balm to high-fat diet elevated the level of total protein beyond the limits of the normal values, while lavender has not. At the same time, in all groups, we observed slight increase in globuline fraction, especially noted at addition of Vitex.

High-fat diet did not significantly affect the morphological composition of blood of the experimental animals. Almost all the parameters were within the reference values. Exception was the level of monocytes in blood, which in all the groups was 1.5-2.0 times above the normal parameters. Intake of dry shoots of $L$. angustifolia and $M$. officinalis contributed to significant increase in the concentration of leukocytes in blood (to $165.4 \%$ and $199.9 \%$ of the concentration in the control group, respectively), but did not exceed the thresholds of the reference values (Table 4). Consumption of dry herbs of $V$. angus-castus stimulated decrease in con- centration of band neutrophils in blood of rats (four times lower than in the control group, Table 4). General analysis of blood and leukogram of male rats revealed no other significant changes.

Physical activity (Fig. 3a) of the animals was significantly reduced by the end of the experiment after consumption of $L$. angustifolia snd M. officinalis. Under the influence of these plants, orienting activity of the rats also decreased significantly (Fig. 3b). No significant changes in emotional status (Fig. 3c) were seen during the experiment when the animals were fed with all three species of medicinal plants. Addition of the shoots of $V$. angus-castus led to no changes in physical and oriented activity of animals (Fig. 3). Significant changes in the "open field" test at the beginning and the end of the experiment were observed between and inside the groups of rats (Table 5) that consumed the shoots of $L$. angustifolia and M. officinalis for the quantity of the attended peripheral squares and the number of stances in the peripheral squares.

\section{Table 3}

Change in biochemical parameters of blood of males of rats under effect of addition of crumbled shoots of Lavandula angustifolia Mill., Melissa officinalis $\mathrm{L}$. and Vitex angus-castus $\mathrm{L}$. $(\mathrm{x} \pm \mathrm{SD}, \mathrm{n}=8$, duration of experiment -30 days)

\begin{tabular}{|c|c|c|c|c|c|c|c|}
\hline Parameters & Control & L. angustifolia & $\begin{array}{l}\text { L. angustifolia } \\
\text { compared to the } \\
\text { control, } \%\end{array}$ & M. officinalis & $\begin{array}{l}\text { M. officinalis } \\
\text { compared to the } \\
\text { control, } \%\end{array}$ & V. angus-castus & $\begin{array}{l}V \text {. angus-castus } \\
\text { compared to the } \\
\text { control, } \%\end{array}$ \\
\hline Total protein, $\mathrm{g} / \mathrm{L}$ & $77.0 \pm 4.9$ & $76.0 \pm 4.0$ & 98.7 & $80.0 \pm 3.7$ & 103.9 & $86.4 \pm 4.7^{*}$ & 112.2 \\
\hline Albumins, $\mathrm{g} / \mathrm{L}$ & $39.6 \pm 2.6$ & $38.7 \pm 2.5$ & 97.8 & $41.3 \pm 2.2$ & 104.3 & $44.0 \pm 1.7$ & 111.2 \\
\hline Globulins, $\mathrm{g} / \mathrm{L}$ & $37.4 \pm 3.9$ & $37.3 \pm 3.3$ & 99.6 & $38.7 \pm 3.3$ & 103.4 & $42.4 \pm 3.8$ & 113.4 \\
\hline Protein coefficient, $U$ & $1.10 \pm 0.15$ & $1.06 \pm 0.12$ & 96.1 & $1.09 \pm 0.14$ & 98.7 & $1.04 \pm 0.09$ & 94.8 \\
\hline Urea, $\mathrm{mmol} / \mathrm{L}$ & $6.84 \pm 1.02$ & $6.00 \pm 0.74$ & 87.7 & $5.40 \pm 0.58$ & 78.9 & $5.13 \pm 1.48$ & 74.9 \\
\hline Urea nitrogen, $\mathrm{mg} / 100 \mathrm{~g}$ & $13.1 \pm 2.0$ & $11.5 \pm 1.4$ & 87.7 & $10.3 \pm 1.1^{*}$ & 79.0 & $10.6 \pm 1.4$ & 81.3 \\
\hline Creatinine, $\mu \mathrm{mol} / \mathrm{L}$ & $63.0 \pm 4.4$ & $61.0 \pm 7.4$ & 96.8 & $74.9 \pm 12.8$ & 118.8 & $67.0 \pm 11.5$ & 106.3 \\
\hline Aspartate aminotransferase (AST), U/L & $186 \pm 61$ & $160 \pm 48$ & 85.7 & $182 \pm 33$ & 97.8 & $191 \pm 39$ & 102.3 \\
\hline Alanine aminotransferase (ALT), U/L & $131 \pm 41$ & $129 \pm 39$ & 98.5 & $111 \pm 18$ & 85.2 & $179 \pm 46$ & 136.8 \\
\hline De Ritis ratio (AST/ALT), $U$ & $1.63 \pm 0.78$ & $1.37 \pm 0.45$ & 84.2 & $1.64 \pm 0.30$ & 100.9 & $0.94 \pm 0.43$ & 57.9 \\
\hline Alkaline phosphatase, $\mathrm{U} / \mathrm{L}$ & $129 \pm 64$ & $451 \pm 94 * * *$ & 349.7 & $601 \pm 149 * * *$ & 465.7 & $524 \pm 143^{* * * *}$ & 406.2 \\
\hline Total bilirubin, $\mu \mathrm{mol} / \mathrm{L}$ & $6.1 \pm 1.7$ & $4.1 \pm 2.8$ & 67.3 & $3.8 \pm 1.4^{*}$ & 63.3 & $5.7 \pm 1.5$ & 93.6 \\
\hline Glucose, $\mathrm{mmol} / \mathrm{L}$ & $7.39 \pm 1.04$ & $6.36 \pm 0.63$ & 86.1 & $6.40 \pm 0.55$ & 86.7 & $5.97 \pm 0.58^{*}$ & 80.9 \\
\hline Totalcalcium, $\mathrm{mmol} / \mathrm{L}$ & $2.53 \pm 0.09$ & $2.51 \pm 0.11$ & 99.4 & $2.59 \pm 0.14$ & 102.3 & $2.59 \pm 0.16$ & 102.3 \\
\hline Non-organic phosphorus, $\mathrm{mmol} / \mathrm{L}$ & $3.07 \pm 0.58$ & $3.67 \pm 0.40$ & 119.5 & $3.46 \pm 0.29$ & 112.6 & $3.13 \pm 0.57$ & 101.9 \\
\hline RatioofCa/P & $0.843 \pm 0.129$ & $0.686 \pm 0.099$ & 81.4 & $0.743 \pm 0.090$ & 88.1 & $0.857 \pm 0.192$ & 101.7 \\
\hline $\begin{array}{l}\text { Gamma-glutamyl transpeptidase } \\
\text { (GGT), units/L }\end{array}$ & $9.3 \pm 2.6$ & $9.1 \pm 4.4$ & 98.5 & $6.7 \pm 0.7$ & 72.3 & $6.4 \pm 1.2$ & 69.2 \\
\hline Cholesterol, $\mathrm{mmol} / \mathrm{L}$ & $1.27 \pm 0.13$ & $1.59 \pm 0.20^{*}$ & 124.7 & $1.43 \pm 0.18$ & 112.4 & $1.43 \pm 0.07$ & 112.4 \\
\hline Tryglicerides, $\mathrm{mmol} / \mathrm{L}$ & $2.13 \pm 0.55$ & $1.36 \pm 0.38$ & 63.8 & $1.34 \pm 0.31^{*}$ & 63.1 & $1.20 \pm 0.38^{* *}$ & 56.4 \\
\hline $\begin{array}{l}\text { High-dense lipoprotein cholesterol } \\
\text { (HDL cholesterol),mmol/L }\end{array}$ & $0.65 \pm 0.13$ & $0.66 \pm 0.19$ & 101.5 & $0.80 \pm 0.44$ & 122.6 & $0.34 \pm 0.24 *$ & 51.9 \\
\hline $\begin{array}{l}\text { Low-dense lipoprotein cholesterol } \\
\text { (LDL cholesterol), } \mathrm{mmol} / \mathrm{L}\end{array}$ & $0.52 \pm 0.29$ & $1.18 \pm 0.08^{* * *}$ & 227.7 & $0.51 \pm 0.11$ & 98.0 & $0.95 \pm 0.40$ & 184.3 \\
\hline C-reactive protein, $\mathrm{mg} / \mathrm{L}$ & $12.5 \pm 5.4$ & $13.2 \pm 5.2$ & 105.7 & $10.2 \pm 1.4$ & 81.7 & $12.6 \pm 3.0$ & 100.3 \\
\hline Aterogenecity index, units & $1.04 \pm 0.45$ & $1.85 \pm 1.41$ & 177.1 & $1.30 \pm 0.91$ & 124.5 & $5.57 \pm 3.32^{* * *}$ & 524.0 \\
\hline
\end{tabular}

Note: see Table 1.

\section{Table 4}

Change in general analysis of blood and leukogram of male rats under effect of intake of crumbled shoots of Lavandula angustifolia Mill., Melissa officinalis $\mathrm{L}$. and Vitex angus-castus $\mathrm{L} .(\mathrm{x} \pm \mathrm{SD}, \mathrm{n}=8$, duration of experiment-30 days)

\begin{tabular}{|c|c|c|c|c|c|c|c|}
\hline Parameter & Control & L. angustifolia & $\begin{array}{l}\text { L. angustifolia } \\
\text { compared to the } \\
\text { control, } \%\end{array}$ & M. officinalis & $\begin{array}{c}\text { M. officinalis com- } \\
\text { pared to the control, } \\
\%\end{array}$ & V. angus-castus & $\begin{array}{l}V . \text { angus-castus } \\
\text { compared to the } \\
\text { control, } \%\end{array}$ \\
\hline Hemoglobin, $g / L$ & $126.8 \pm 7.0$ & $119.3 \pm 7.1$ & 94.1 & $130.4 \pm 6.9$ & 102.8 & $126.7 \pm 11.8$ & 99.9 \\
\hline Hematocrit, $\%$ & $40.5 \pm 2.7$ & $38.6 \pm 2.4$ & 95.3 & $42.0 \pm 1.9$ & 103.6 & $40.3 \pm 4.0$ & 99.5 \\
\hline Erythrocytes, $10^{12} / \mathrm{L}$ & $6.93 \pm 0.29$ & $7.13 \pm 0.30$ & 102.8 & $7.03 \pm 0.91$ & 101.3 & $7.32 \pm 0.67$ & 105.6 \\
\hline $\begin{array}{l}\text { Erythrocyte sedimentation rate } \\
\text { (ESR), } \mathrm{mm} / \mathrm{h}\end{array}$ & $1.17 \pm 0.37$ & $1.33 \pm 0.47$ & 114.3 & $1.00 \pm 0.00$ & 85.7 & $1.00 \pm 0.00$ & 85.7 \\
\hline Thrombocytes, $10^{9} / \mathrm{L}$ & $339 \pm 66$ & $351 \pm 87$ & 103.7 & $336 \pm 66$ & 99.3 & $284 \pm 72$ & 83.7 \\
\hline Leukocytes, $10^{9} / \mathrm{L}$ & $8.6 \pm 1.6$ & $14.2 \pm 2.3^{* * *}$ & 165.4 & $17.1 \pm 5.9^{* * *}$ & 199.9 & $11.3 \pm 6.1$ & 131.6 \\
\hline \multicolumn{8}{|l|}{ Leukocytic formula } \\
\hline Basophils, $\%$ & $0.0 \pm 0.0$ & $0.0 \pm 0.0$ & 0.0 & $0.0 \pm 0.0$ & 0.0 & $0.0 \pm 0.0$ & 0.0 \\
\hline Eosinophils, \% & $1.50 \pm 0.76$ & $1.17 \pm 0.37$ & 77.8 & $1.57 \pm 0.73$ & 104.8 & $0.86 \pm 0.35$ & 57.1 \\
\hline Mielocits, \% & $0.0 \pm 0.0$ & $0.0 \pm 0.0$ & 0.0 & $0.0 \pm 0.0$ & 0.0 & $0.0 \pm 0.0$ & 0.0 \\
\hline Neutrophils, \%: & & & & & & & \\
\hline -young & $0.0 \pm 0.0$ & $0.0 \pm 0.0$ & 0.0 & $0.0 \pm 0.0$ & 0.0 & $0.0 \pm 0.0$ & 0.0 \\
\hline -band & $1.17 \pm 0.69$ & $1.17 \pm 1.07$ & 100.0 & $0.71 \pm 0.45$ & 61.2 & $0.29 \pm 0.45^{*}$ & 24.5 \\
\hline - with segmented nuclei & $23.0 \pm 8.2$ & $22.3 \pm 5.1$ & 97.1 & $25.6 \pm 6.4$ & 111.2 & $21.0 \pm 4.4$ & 91.3 \\
\hline Lymphocytes, \% & $68.8 \pm 8.6$ & $67.2 \pm 6.3$ & 97.6 & $65.9 \pm 6.9$ & 95.7 & $72.1 \pm 3.6$ & 104.8 \\
\hline Monocytes, \% & $5.5 \pm 1.3$ & $8.2 \pm 3.3$ & 148.5 & $6.3 \pm 2.3$ & 114.3 & $5.6 \pm 1.7$ & 101.3 \\
\hline
\end{tabular}

Note: see Table 1. 

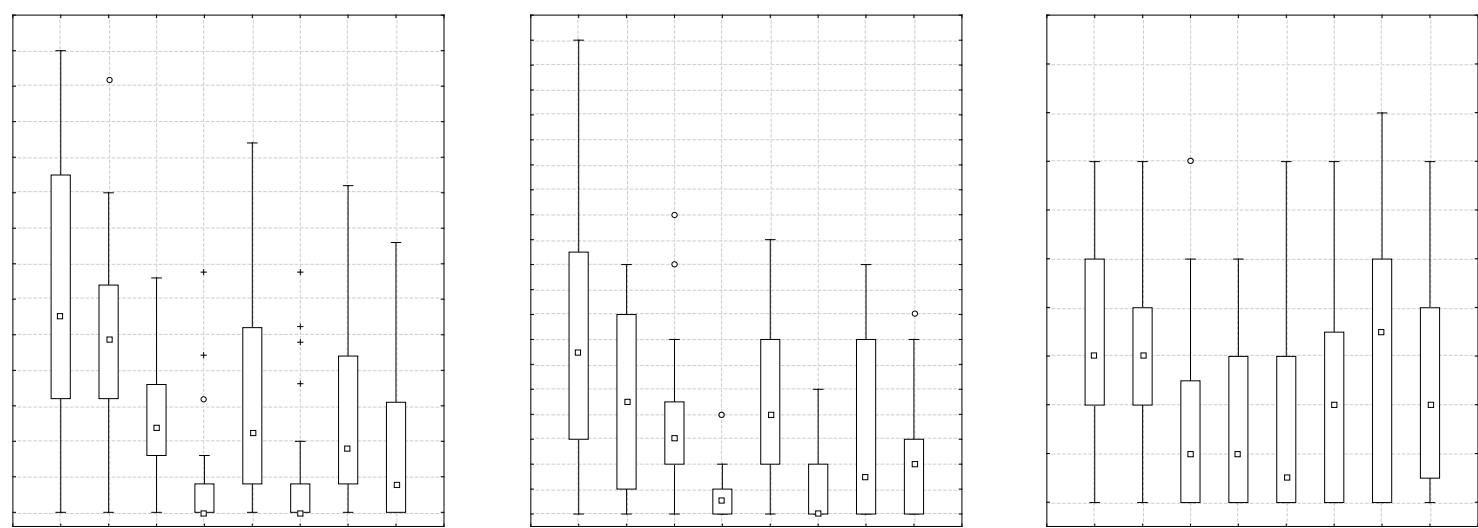

$a$

$b$

$c$

Fig. 3. Changes in the motor activity $(a)$, orienting activity $(b)$ and emotional status $(c)$ of male rats that in addition to their diet received crumbled shoots of Lavandula angustifolia Mill., Melissa officinalis L. and Vitex angus-castus L.: on abscissa axis - groups of animals $(\mathrm{n}=8)$ on the diet with excessive fat content and addition of grined shoots of the plants (in parentheses there are indicated day after the experiment: beginning - 1-4th or the end - 26-30th days), on ordinate axis - absolute number of markers of this type of behavior during 120 seconds of the experiment: for the motor activity - the number of attended squares of the "open field", for the orienting activity - number of stances, for the emotional status - number of acts of grooming, defecation and urination; small square - median, the upper and lower line of the rectangle $-75 \%$ and $25 \%$ quartiles, the upper line - minimum and maximum values, circles - emissions; different letters within each figure indicate significant differences between the groups $(\mathrm{P}<0.05)$ according to the results of Tukey test

\section{Table 5}

Changes in the behaviouristic characteristics of the three groups of rats during 120 seconds of the experiment when crumbled shoots of Lavandula angustifolia Mill., Melissa officinais L. and Vitex angus-castus $\mathrm{L}$. were added to the $\operatorname{diet}(\mathrm{x} \pm \mathrm{SD}, \mathrm{n}=32$, duration of the experiment was 30 days)

\begin{tabular}{|c|c|c|c|c|c|c|c|c|}
\hline Characteristic & $\begin{array}{l}\text { Control, } \\
\text { 1-4th days }\end{array}$ & $\begin{array}{c}\text { Control, } \\
\text { 26-30th days }\end{array}$ & $\begin{array}{l}\text { L. angustifolia, } \\
\text { 1-4th days }\end{array}$ & $\begin{array}{l}\text { L. angustifolia } \\
\text { 26-30th days }\end{array}$ & $\begin{array}{c}\text { M. officinalis, } \\
\text { 1-4th days }\end{array}$ & $\begin{array}{l}\text { M. officinalis, } \\
\text { 26-30th days }\end{array}$ & $\begin{array}{l}\text { V. angus- } \\
\text { castus, } \\
\text { 1-4th days }\end{array}$ & $\begin{array}{c}\text { V. angus- } \\
\text { castus, } \\
\text { 26-30th days }\end{array}$ \\
\hline $\begin{array}{l}\text { Number of attended periphery } \\
\text { squares }\end{array}$ & 8.13 & $24.33 \pm 14.4$ & & $71+$ & & & $13.54=$ & 8.96 \\
\hline Number of attended central squares & $1.00 \pm 2.341$ & $0.292 \pm 1.042$ & $0.00 \pm 0.00$ & $0.00 \pm 0.00$ & $0.821 \pm 1.887$ & $0.000 \pm 0.000$ & $0.107 \pm 0.416$ & $0.000 \pm 0.000$ \\
\hline $\begin{array}{l}\text { Number of stances in peripheral } \\
\text { squares }\end{array}$ & & & & & & & & \\
\hline $\begin{array}{l}\text { Number of stances in the central } \\
\text { squares }\end{array}$ & $1.292 \pm 1.429$ & $0.708 \pm 0.999$ & $0.607 \pm 0.994$ & $0.036 \pm 0.189$ & $0.750 \pm 1.602$ & $0.000 \pm 0.000$ & $0.222 \pm 0.641$ & $0.000 \pm 0.000$ \\
\hline Number of acts of groomin & & 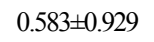 & $1.000 \pm 1.122$ & $0.536 \pm 0.744$ & & 4 & 0.393 & 0.393 \\
\hline Numb & & & & & & & 2.679 & $2.179 \pm 2.195$ \\
\hline Number of urinations & $0.333 \pm 0.482$ & $0.375 \pm 0.495$ & $0.107 \pm 0.416$ & $0.036 \pm 0.189$ & $0.036 \pm 0.189$ & $0.036 \pm 0.189$ & $0.000 \pm 0.000$ & $0.000 \pm 0.000$ \\
\hline
\end{tabular}

Notes: no significant differences between the groups were found according to most of the parameters; differences between the number of attended peripheral squares and the number of stances in the peripheral squares are indicated by different latin letters $(\mathrm{P}<0.05)$, according to Tukey test.

\section{Discussion}

Plant-based food supplements are currently gaining popularity, but the data about the risk they pose are rare and contravercial. Lamiaceae family contains herbs of high socio-economic significance, several horticultural and ornamental species, culinary herbs, having broad range of application because of richness in phenolic compounds (Trivellini et al., 2016). Natural phenols are less harmful to the environment and health than components used in cosmetics, pesticides and preservatives (Trivellini et al., 2016). Obesity and overating are some commonest health issues around the world, and many people see easy solution in the performance and image-enhancing drugs (PIEDs). Nonetheless, those preparations may exert toxicity and impair metabolism, despite the manufacturers' claims about safety of the natural receipes of their medicinal drugs (Bersani et al., 2015).

Identifying the composition of biologically active compounds in medicinal herbs is complicated because there are no unified methods for this purpose (Milevskaya et al., 2019). Therefore, in our study, we chose to add dry crumbled plants to granulated feed of animals.

In our study, addition of lavender and lemon balm to the diet was followed by more intense weight gain while consuming less food than the control group that received high-fat diet.
Valable medicinal plant $M$. officinalis is native to the eastern Mediterranean Region and Western Asia. Its main constituents are citral (geranial and neral), citronellal, geraniol. In the experiments, $M$. officinalis notably decreased body weight (Valizadeh et al., 2016); nonetheless, the review emphasizes that there are needed randomized trials of higher quality to confirm the results. Abilities to improve memory had been also demonstrated by some other plants like M. officinalis, and the mechanisms of action were determined (Shojaii et al., 2016), but for many medicinal herbs there is not a sufficient amount of studies on their efficiency in improving memory and learning (Shojaii et al., 2016).

Many pharmacological effects have been reported for crude extracts and pure compounds isolated from M. officinalis, but only anxiolytic, antiviral, antispasmodic activities, as well as effects on mood, cognition and memory were confirmed in the clinical experiments. The major mechanisms of this plant's neurological effects, which are the subject of discussion worldwide, are $\mathrm{AChE}$ inhibitory activity, stimulation of the acetylcholine and GABA(A) receptors, as well as inhibition of matrix metallo proteinase-2 (Shakeri et al., 2016). Lemon balm is applied during a number of health issues, particularly anxiety and some other disorders of the central nervous system, but substantiation of its effects needs trials in clinical settings (Shakeri et al., 2016). The most frequent clinical effects of application plant food supplements that contained M. officinalis were 
neurotoxicity and gastro-intestinal symptoms. The symptoms in most cases were mild (Lude et al., 2016).

High content of fat in diet is considered to inevitably cause increase in the parameters of lipid metabolism such as total cholesterol, level of triglycerides, content and proportion of lypoproteins of different density, which are expressed by such a parameter as aterogenecity index. In our experiments, in rats, the consumption of the diet with heightened content of fat during 30 days caused no elevation of the level of total cholesterol, which remained within the reference values. As known, the parameters of lipid metabolism in rats were lower than such in human due to production of specific bile acids $-\alpha$ - and $\beta$-muricholic acids, absent in humans (Thomas et al., 1984). Bile acids in particular are those considered responsible for fast removal of cholesterol from the rats' organisms. Difference lies in the fact that rats are very resistant to the level of serum cholesterol, unlike human. Moreover, the animals are hardly vulnerable to development of plaques in the arteries as a result of intake of cholesterol-rich food (Stehbens, 1986).

Gross et al. (2019) reported that $M$. officinalis was clinically effective against symptoms related to anxiety and displayed no signs of toxicity. The review by Swiader et al. (2019) analyzed the literature data on the chemical composition of $M$. officinalis and the possibilities of using it in medicine and food. Heshmati et al. (2020) indicated the relationship between consumption of $M$. officinalis and decreased total cholesterol and reduced systolic blood pressure. Intake of M. officinalis was not observed to be related to statistically significant changes in triglycerides, low-density lipoprotein, diastolic blood pressure, high sensitivity c-reactive protein levels, fasting blood sugar, $\mathrm{HbAlc}$, insulin or high-density lipoprotein levels. No serious side effects were reported. According to the study by Heshmati et al. (2020), M. officinalis is safe beneficial supplement. In our experiment, addition of lemon balm to high-fat diet of rats reduced the intensity of increase in the level of triglycerides and HDL cholesterol compared with the control, and at the same time the indicator of total cholesterol, LDL cholesterol, did not change significantly.

In a 21-day experiment on rats that received high-fat diet and various doses of extract of melissa, Zarei et al. (2014) observed significant decrease in the activity of hepatic enzymes. In our experiment, by the 30th day, the rats fed with fat diet were seen to AST, ALT and alkaline phosphatase exceeding the reference values, indicating damaged cellular membranes of hepatocytes. Adition of lemon balm to the diet led to decrease in only ALT activity, and AST activity remained the same as in the animals on high-fat diet, and the activity of alkaline phosphatase was significantly higher. This may be related to either longer duration of our experiment or lower dose of active agents.

Benny \& Thomas (2019) analyzed the literature reporting anti-amyloid, antioxidants, anticholinesterase, and memory-enhancement activities of essential oils from M. officinalis, L. angustifolia in preclinical and clinical studies of Alzheimers disease.

Treatment of neurodegenerative diseases with $M$. officinalis and rosmarinic acid - its major constituent - has been reported in many scientific and non-scientific articles, but clinical trial of ethanol extract from $M$. officinalis was only made so far toward Alzheimer disease (Mahboubi, 2019). Action mechanisms of $M$. officinalis comprise inhibitory effects against beta-amyloid, reactive oxygen species, and acetylcholine esterase.

M. officinalis can mitigate psychological symptoms in the patients undergoing operation (Shabanian et al., 2019). Use of medicinal herbs before and after surgery alleviates anxiety, depression, aggressive and impulsive behavior, stress, delirium and cognitive dysfunction. Trials on children with attention deficit hyperactivity disorder (ADHD) who consumed $M$. officinalis preparations showed low evidence for their effectiveness (Anheyer et al., 2017); but no concrete recommendations could be made while there is still a lack of sufficient numbers.

In many studies, $M$. officinalis exerted high antioxidant activity through flavonoids, rosmaric acid, gallic acid, phenolic contents. A number of studies confirmed the antioxidative action of M. officinalis, and its effect in preventing and treating oxidative stress-related diseases might be reliable (Miraj et al., 2017). Moradi et al. (2016) report that more comprehensive studies using more advanced methods are needed to develop promising anti-HSV drugs based on bioactive compounds isolated from M. officinalis.
Rosmarinic acid is considered to have notable pharmacological effects and was recently surveyed as a therapeutic drugs in treatment of diabetes (Ngo et al., 2018). Earlier researches confirmed that rosmarinic acid can control the plasma glucose level and heighten insulin sensitivity in hyperglycemia. Rosmarinic acid is quickly absorbed in the human body, but its mechanism remains unclear (Ngo et al., 2018). Against the background of high-fat diet, glucose level in blood plasma of the studied rats increased, whereas addition of medicinal plants to the diet decreased the glucose level to the normal values.

M. officinalis and $L$. angustifolia are commonly considered to take generally calming effect. Experimental pharmacology using L. angustifolia includes anesthetic, anticonvulsant, sedative, anti-inflammatory, antimicrobial, antispasmodic, antispasmodic, central nervous system depressant effects; clinical pharmacology includes anxiolytic, analgesic, and cardiovascular effects (Koriem, 2021). In the quantitative synthesis, inhalation of lavender decreased levels of anxiety, according to any validated scale and sign of anxiety (Donelli et al., 2019), but caused no reduction of blood pressure, a physiological parameter of anxiety. Investigation of effects of inhalation of lavender oil aroma in sleep needs more in-detail surveys (Fismer \& Pilkington, 2012). Some studies have shown the effiency of oral lavender supplements, but independent replications are needed to draw conclusions (Perry et al., 2012). In the "open field" method, addition of lavender and lemon balm perorally with food significantly decreased motor activity of animals, compared with the control group (high-fat diet). Also, these animals exhibited decrease in orienting activity. Despite some data on vitex manifesting calming effect (Mehlhorn, 2016), it exhibited no inhibition of motor and orienting activities in our experiment. Moreover, all the studied plants caused no changes in the emotional status of the experimental rats.

V. agnus-castus is rich in phytoestrogens and is traditionally applied in the treatment of premenstrual syndrome (Arzi et al., 2019). In the rat groups, no anti-anxiety effects were manifested by tamoxifen or a combination of tamoxifen and a high dose of $V$. angus-castus. Extract from $V$. agnus-castus displayed anti-anxiety activity and may be used to treat anxiety (Mehlhorn, 2016). Interaction between phytoestrogens from V. agnus-castus and estrogen receptors could be the mechanism that determines the plant's anxiolytic activity (Arzi et al., 2019).

Effects of the plants we tested on the organism of rats were both direct and indirect: by inhibiting certain species of microorganisms in the intestine of animals (Bilan et al., 2019). In our earlier experiments, ethanol extract from $M$. officinalis powerfully inhibited growth of colonies of bacteria of Salmonella typhimurium, poorly inhibited such of Escherichia coli, Klebsiella pneumonia and Corinebacterium xerosis, and caused no effect on Proteus mirabilis, Listeria monocytogenes and fungus of Candida albicans (Zazharskyi et al., 2019). Similar effects were observed for ethyl extract of the leaves of L. angustifolia: it notably inhibited growth of colonies of Salmonella typhimurium and Klebsiella pneumonia, weakly affected Escherichia coli, Proteus mirabilis and fungus of Candida albicans and inhibited no growth of cells of bacteria of Listeria monocytogenes and Corinebacterium xerosis (Zazharskyi et al., 2019). We seen broader range of antibacterial activity in in vitro experiments exhibited by ethyl extract from $V$. angus-castus that notably inhibited growth of Corinebacterium xerosis, Serratia marcescens, Salmonella typhimurium, Proteus mirabilis; weakly affected growth of colonies of Rhodococcus equi, Pseudomonas aeruginosa, Yersinia enterocolitica, Klebsiella pneumonia, Enterococcus faecalis, Escherichia coli, and took no inhibitory effect on growth of colonies of Enterobacter aerogenes, Listeria ivanovi, L. innocua, L. monocytogenes, Campylobacter jejuni and fungus of Candida albicans (Zazharskyi et al., 2020).

Also, in our previous studies, we determined that aqueous tincture of $V$. angus-castus in in vitro experiment had weak lethal effect on larvae of parasitic intestinal nematodes of Strongyloides papillosus (Wedl, 1856), though mortality of nematodes of Haemonchus contortus (Rudolphi, 1803) in aqueous tincture of this plants was no different from the control (Boyko et al., 2020). Essential oil from L. officinalis had similar effect on these species of nematodes, causing 4-fold increase in mortality of larvae of S. papillosus, but took no effect on larvae of $H$. contortus (Boyko \& Brygadyrenko, 2021). Thus, possible effect of medicinal plants of Lamiaceae family may likely occur through various species of parasitic nema- 
todes of Strongyloides genus, specific various species of model animals and human.

\section{Conclusion}

Against the background of high-fat diet, lemon balm and lavender manifested similar influences. Addition of these plants to the diet led to significant decrease in food intake, and at the same time the intensity of weight gain was greater than in the animals that consumed high-fat diet supplemented by vitex. Taking into account that during consumption of lavender and lemon balm, the motor and orienting activities of the animals decreased by the end of the experiment, we consider it as manifestation of calming effect taken by the plant, which was not observed in the control group and with addition of vitex. Also, lemon balm and lavender, by the end of the experiment, led to significant decrease in the relative weights of the brain and the thymus.

High-fat diet caused impairment of metabolism of animals. Addition of medicinal plants to the diet with high content of fat alleviates the disorders in the metabolisms of fat (increase in the level of triglycerides) and carbohydrates (increase in glucose level), but takes negative effect on protein metabolism (hyperproteinemia as a result of hyperglobulinemia).

Additional of medicinal plants to high-fat diet led to impaired activity of blood enzymes - alkaline phosphatase, AST and ALT; increase in triglycerides, LDL cholesterol against the background of decrease in HDL cholesterol and normal value of total cholysterol. Also, all the groups were characteristic of monocytosis, more notable at addition of lavender and lemon balm to the diet, which also caused leukocytosis compared with the control group and addition of vitex.

\section{References}

Akbarzadeh, M., Dehghani, M., Moshfeghy, Z., Emamghoreishi, M., Tavakoli, P., \& Zare, N. (2015). Effect of Melissa officinalis capsule on the intensity of premenstrual syndrome symptoms in high school girl students. Nursing and Midwifery Studies, 4(2), e27001.

Anheyer, D., Lauche, R., Schumann, D., Dobos, G., \& Cramer, H. (2017). Herbal medicines in children with attention deficit hyperactivity disorder (ADHD): A systematic review. Complementary Therapies in Medicine, 30, 14-23.

Aprotosoaie, A. C., Hancianu, M., Costache, I. I., \& Miron, A. (2014). Linalool: A review on a key odorant molecule with valuable biological properties. Flavour and Fragrance Journal, 29(4), 193-219.

Arika, W. M., Kibiti, C. M., Njagi, J. M., \& Ngugi, M. P. (2019). Effects of DCM leaf extract of Gnidia glauca (Fresen) on locomotor activity, anxiety, and exploration-like behaviors in high-fat diet-induced obese rats. Behavioural Neurology, 2019, 7359235 .

Artz, M. B. (2007). Vitex agnus-castus. In: Tracy, T. S., \& Kingston, R. L. (Eds.). Herbal products. Toxicology and clinical pharmacology. Forensic science and medicine. Humana Press. Pp. 245-258.

Arzi, A., Mojiri-Forushani, H., \& Karampour, N. S. (2019). Evaluation of the anxiolytic effect of Vitex agnus-castus on female mice and possible role of estrogen receptors. Jundishapur Journal of Natural Pharmaceutical Products, 14(2), e63570.

Ayaz, M., Sadiq, A., Junaid, M., Ullah, F., Subhan, F., \& Ahmed, J. (2017). Neuroprotective and anti-aging potentials of essential oils from aromatic and medicinal plants. Frontiers in Aging Neuroscience, 9, 168.

Bailly, C. (2020). Targets and pathways involved in the antitumor activity of citral and its stereo-isomers. European Journal of Pharmacology, 871, 172945.

Bayat, M., Azami Tameh, A., Hossein Ghahremani, M., Akbari, M., Mehr, S. E., Khanavi, M., \& Hassanzadeh, G. (2012). Neuroprotective properties of Melissa officinalis after hypoxic-ischemic injury both in vitro and in vivo. Daru: Journal of Faculty of Pharmacy, Tehran University of Medical Sciences, 20(1), 42.

Belova, M. M., Shipunova, V. O., Kotelnikova, P. A., Babenyshev, A. V., Rogozhin, E. A., Cherednichenko, M. Y., \& Deyev, S. M. (2019). "Green" synthesis of cytotoxic silver nanoparticles based on secondary metabolites of Lavandula angustifolia Mill. Acta Naturae, 11(2), 47-53.

Benny, A., \& Thomas, J. (2019). Essential oils as treatment strategy for Alzheimers disease: Current and future perspectives. Planta Medica, 85(3), 239-248.

Bersani, F. S., Coviello, M., Imperatori, C., Francesconi, M., Hough, C. M., Valeriani, G., De Stefano, G., Posocco, F. B. M., Santacroce, R., Minichino, A., \& Corazza, O. (2015). Adverse psychiatric effects associated with herbal weight-loss products. Biomed Research International, 2015, 120679.

Bilan, M. V., Lieshchova, M. A., Tishkina, N. M., \& Brygadyrenko, V. V. (2019). Combined effect of glyphosate, saccharin and sodium benzoate on the gut microbiota of rats. Regulatory Mechanisms in Biosystems, 10(2), 228-232.
Bojic, M., Males, Z., Antolic, A., Babic, I., \& Tomicic, M. (2019). Antithrombotic activity of flavonoids and polyphenols rich plant species. Acta Pharmaceutica, 69(4), 483-495.

Boukhatem, M. N., Sudha, T., Darwish, N., Chader, H., Belkadi, A., Rajabi, M., Houche, A., Benkebailli, F., Oudjida, F., \& Mousa, S. A. (2020). A new eucalyptol-rich lavender (Lavandula stoechas L.) essential oil: Emerging potential for therapy against inflammation and cancer. Molecules, 25(16), 3671.

Bounihi, A., Hajjaj, G., Alnamer, R., Cherrah, Y., \& Zellou, A. (2013). In vivo potential anti-inflammatory activity of Melissa officinalis L. essential oil. Advances in Pharmacological Sciences, 2013, 101759.

Boyko, O. O., Kabar, A. M., \& Brygadyrenko, V. V. (2020). Nematicidal activity of aqueous tinctures of medicinal plants against larvae of the nematodes Strongyloides papillosus and Haemonchus contortus. Biosystems Diversity, 28(1), 119-123.

Boyko, O., \& Brygadyrenko, V. (2021). Nematicidal activity of essential oils of medicinal plants. Folia Oecologica, 48(1), 42-48.

Brown, D., \& Murray, M. T. (2012). Vitex agnus castus (Chaste tree). In: Pizzorno, J., \& Murray, M. (Eds.). Textbook of natural medicine. Churchill Livingstone. Pp. 1135-1139.

Brygadyrenko, V. V., Lieshchova, M. A., Bilan, M. V., Tishkina, N. M., \& Horchanok, A. V. (2019). Effect of alcohol tincture of Aralia elata on the organism of rats and their gut microbiota against the background of excessive fat diet. Regulatory Mechanisms in Biosystems, 10(4), 497-506.

Bukvicki, D., Gottardi, D., Prasad, S., Novakovic, M., Marin, P. D., \& Tyagi, A. K (2020). The healing effects of spices in chronic diseases. Current Medicinal Chemistry, 27(26), 4401-4420.

Cardia, G., Silva-Filho, S. E., Silva, E. L., Uchida, N. S., Cavalcante, H., Cassarotti, L. L., Salvadego, V., Spironello, R. A., Bersani-Amado, C. A., \& Cuman, R. (2018). Effect of lavender (Lavandula angustifolia) essential oil on acute inflammatory response. Evidence-Based Complementary and Alternative Medicine, 2018, 1413940.

Cavanagh, H. M. A., \& Wilkinson, J. N. (2002). Biological activities of lavender essential oil. Phytotherapy Research, 16(4), 301-308.

Clifford, M. N. (1999). Chlorogenic acids and other cinnamates - nature, occurrence and dietary burden. Journal of the Science of Food and Agriculture, 79(3), 362372.

de Cássia da Silveira e Sá, R., Andrade, L. N., \& de Sousa, D. P. (2013). A review on anti-inflammatory activity of monoterpenes. Molecules, 18(1), 1227-1254.

Dobetsberger, C., \& Buchbauer, G. (2011). Actions of essential oils on the central nervous system: An updated review. Flavour and Fragrance Journal, 26(5), 300-316.

Dolatabadi, F., Abdolghaffari, A. H., Farzaei, M. H., Baeeri, M., Ziarani, F. S., Eslami, M., Abdollahi, M., \& Rahimi, R. (2018). The protective effect of Melissa officinalis L. in visceral hypersensitivity in rat using 2 models of acid-induced colitis and stress-induced irritable bowel syndrome: A possible role of nitric oxide pathway. Journal of Neurogastroenterology and Motility, 24(3), 490-501.

Donelli, D., Antonelli, M., Bellinazzi, C., Gensini, G. F., \& Firenzuoli, F. (2019). Effects of lavender on anxiety: A systematic review and meta-analysis. Phytomedicine, $65,153099$.

EFSA Panel on Additives and Products or Substances used in Animal Feed (FEEDAP), Bampidis, V., Azimonti, G., Bastos, M. L., Christensen, H., Kouba, M., Kos Durjava, M., López-Alonso, M., López Puente, S., Marcon, F., Mayo, B., Pechová, A., Petkova, M., Ramos, F., Sanz, Y., Villa, R. E., Woutersen, R., Brantom, P., Chesson, A., Westendorf, J., Gregoretti, L., Manini, P., \& Dusemund, B. (2020). Safety and efficacy of a dried aqueous ethanol extract of $\mathrm{Me}$ lissa officinalis L. leaves when used as a sensory additive for all animal species. EFSA Journal, 18(2), e06016.

Eivani, M., \& Khosronezhad, N. (2020). Melissa officinalis: A memory enhancer remedy. Physiology and Pharmacology, 24(3), 159-164.

Feliú-Hemmelmann, K., Monsalve, F., \& Rivera, C. (2013). Melissa officinalis and Passiflora caerulea infusion as physiological stress decreaser. International Journal of Clinical and Experimental Medicine, 6(6), $444-451$.

Fismer, K. L., \& Pilkington, K. (2012). Lavender and sleep: A systematic review of the evidence. European Journal of Integrative Medicine, 4(4), E436-E447.

Gangemi, S., Minciullo, P. L., Miroddi, M., Chinou, I., Calapai, G., \& Schmidt, R. J. (2015). Contact dermatitis as an adverse reaction to some topically used European herbal medicinal products - Part 2: Echinacea purpurea - Lavandula angustifolia. Contact Dermatitis, 72(4), 193-205.

Greff, B., Lakatos, E., Szigeti, J., \& Varga, L. (2020). Co-composting with herbal wastes: Potential effects of essential oil residues on microbial pathogens during composting. Critical Reviews in Environmental Science and Technology, 51(5), 457-511.

Gross, A. V., Stolz, E. D., Muller, L. G., Rates, S. M. K., \& Ritter, M. R. (2019). Medicinal plants for the "nerves": A review of ethnobotanical studies carried out in South Brazil. Acta Botanica Brasilica, 33(2), 269-282.

Hamza, A. A., Ahmed, M. M., Elwey, H. M., \& Amin, A. (2016). Melissa officinalis protects against doxorubicin-induced cardiotoxicity in rats and potentiates its anticancer activity on MCF-7 cells. PloS One, 11(11), e0167049. 
Hasanein, P., \& Riahi, H. (2015). Antinociceptive and antihyperglycemic effects of Melissa officinalis essential oil in an experimental model of diabetes. Medical Principles and Practice, 24(1), 47-52.

Häusler, E., Petersen, M., \& Alfermann, A. (1993). Isolation of protoplasts and vacuoles from cell suspension cultures of Coleus blumei Benth. Plant Cell Reports, 12(9), 510-512.

Heghes, S. C., Filip, L., Vostinaru, O., Mogosan, C., Miere, D., Iuga, C. A., \& Moldovan, M. (2020). Essential oil-bearing plants from Balkan Peninsula: Promising sources for new drug candidates for the prevention and treatment of diabetes mellitus and dyslipidemia. Frontiers in Pharmacology, 11, 989.

Heshmati, J., Morvaridzadeh, M., Sepidarkish, M., Fazelian, S., Rahimlou, M., Omidi, A., Palmowski, A., Asadi, A., \& Shidfar, F. (2020). Effects of Melissa officinalis (lemon balm) on cardio-metabolic outcomes: A systematic review and meta-analysis. Phytotherapy Research, 34(12), 3113-3123.

Hitl, M., Kladar, N., Gavaric, N., \& Bozin, B. (2021). Rosmarinic acid - human pharmacokinetics and health benefits. Planta Medica, 87(4), 273-282.

Hosseini, S. R., Kaka, G., Joghataei, M. T., Hooshmandi, M., Sadraie, S. H., Yaghoobi, K., Mansoori, K., \& Mohammadi, A. (2017). Coadministration of dexamethasone and Melissa officinalis has neuroprotective effects in rat animal mode with spinal cord injury. Cell Journal, 19(1), 102-116.

Iranshahy, M., \& Javadi, B. (2019). Diet therapy for the treatment of Alzheimer's disease in view of traditional Persian medicine: A review. Iranian Journal of Basic Medical Sciences, 22(10), 1102-1117.

Jeung, I. C., Jee, D., Rho, C. R., \& Kang, S. (2016). Melissa officinalis L. extracts protect human retinal pigment epithelial cells against oxidative stress-induced apoptosis. International Journal of Medical Sciences, 13(2), 139-146.

Joukar, S., \& Asadipour, H. (2015). Evaluation of Melissa officinalis (lemon balm) effects on heart electrical system. Research in Cardiovascular Medicine, 4(2) e27013.

Joukar, S., Zarisfi, Z., Sepehri, G., \& Bashiri, A. (2014). Efficacy of Melissa officinalis in suppressing ventricular arrhythmias following ischemia-reperfusion of the heart: A comparison with amiodarone. Medical Principles and Practice, 23(4), 340-345.

Kaka, G., Yaghoobi, K., Davoodi, S., Hosseini, S. R., Sadraie, S. H., \& Mansouri, K (2016). Assessment of the neuroprotective effects of Lavandula angustifolia extract on the contusive model of spinal cord injury in wistar rats. Frontiers in Neuroscience, 10,25 .

Karabagias, I. K., Karabagias, V. K., \& Riganakos, K. A. (2019). Physico-chemica parameters, phenolic profile, in vitro antioxidant activity and volatile compounds of ladastacho (Lavandula stoechas) from the region of Saidona. Antioxidants, 8(4), 80 .

Kennedy, D. O., \& Wightman, E. L. (2011). Herbal extracts and phytochemicals: Plant secondary metabolites and the enhancement of human brain function. Advances in Nutrition, 2(1), 32-50.

Kikuchi, H., Yuan, B., Yuhara, E., Imai, M., Furutani, R., Fukushima, S., Hazama, S., Hirobe, C., Ohyama, K., Takagi, N., \& Toyoda, H. (2014). Involvement of histone H3 phosphorylation via the activation of p38 MAPK pathway and intracellular redox status in cytotoxicity of HL-60 cells induced by Vitex agnuscastus fruit extract. International Journal of Oncology, 45(2), 843-852.

Kim, J., Lee, H., Lim, J., Oh, J., Shin, S. S., \& Yoon, M. (2017). The angiogenesis inhibitor ALS-L1023 from lemon-balm leaves attenuates high-fat diet-induced nonalcoholic fatty liver disease through regulating the visceral adipose-tissue function. International Journal of Molecular Sciences, 18(4), 846.

Koriem, K. M. M. (2021). Lavandulae aetheroleum oil: A review on phytochemica screening, medicinal applications, and pharmacological effects. Biointerface Research in Applied Chemistry, 11(3), 9836-9847.

Kubo, H., Shibato, J., Saito, T., Ogawa, T., Rakwal, R., \& Shioda, S. (2015). Unraveling the rat intestine, spleen and liver genome-wide transcriptome after the ora administration of lavender oil by a two-color dye-swap DNA microarray approach. PloS One, 10(7), e0129951.

Lee, E. K., Kim, Y. J., Kim, J. Y., Song, H. B., \& Yu, H. G. (2014). Melissa officinalis extract inhibits laser-induced choroidal neovascularization in a rat model. PloS One, 9(10), e110109.

Lesage-Meessen, L., Bou, M., Sigoillot, J. C., Faulds, C. B., \& Lomascolo, A (2015). Essential oils and distilled straws of lavender and lavandin: A review of current use and potential application in white biotechnology. Applied Microbiology and Biotechnology, 99(8), 3375-3385.

Lieshchova, M. A., Bilan, M. V., Bohomaz, A. A., Tishkina, N. M., \& Brygadyrenko, V. V. (2020). Effect of succinic acid on the organism of mice and their intestinal microbiota against the background of excessive fat consumption. Regulatory Mechanisms in Biosystems, 11(2), 153-161.

Lieshchova, M. A., Brygadyrenko, V. V., Tishkina, N. M., Gavrilin, P. M., \& Bohomaz, A. A. (2019). Impact of polyvinyl chloride, polystyrene, and polyethylene on the organism of mice. Regulatory Mechanisms in Biosystems, 10(1), 50-55.

Lieshchova, M. A., Tishkina, N. M., Bohomaz, A. A., Gavrilin, P. M., \& Brygadyrenko, V. V. (2018). Combined effect of glyphosphate, saccharin and sodium benzoate on rats. Regulatory Mechanisms in Biosystems, 9(4), 591-597.
Lude, S., Vecchio, S., Sinno-Tellier, S., Dopter, A., Mustonen, H., Vucinic, S., Jonsson, B., Muller, D., Fruchtengarten, L. V., Hruby, K., Nascimento, E. D., Di Lorenzo, C., Restani, P., Kupferschmidt, H., \& Ceschi, A. (2016). Adverse effects of plant food supplements and plants consumed as food: Results from the poisons centres-based plant Libra study. Phytotherapy Research, 30(6), 988-996.

Lundstrom, K., Pham, H. T., \& Dinh, L. D. (2017). Interaction of plant extracts with central nervous system receptors. Medicines, 4(1), 12

Mahboubi, M. (2019). Melissa officinalis and rosmarinic acid in management of memory functions and Alzheimer disease. Asian Pacific Journal of Tropica Biomedicine, 9(2), 47-52.

Maleki-Saghooni, N., Karimi, F. Z., Moghadam, Z. B., \& Najmabadi, K. M. (2018) The effectiveness and safety of Iranian herbal medicines for treatment of premenstrual syndrome: A systematic review. Avicenna Journal of Phytomedicine, $8(2), 96-113$

Martin, B. R. (2019). Complementary medicine therapies that may assist with weight loss: A narrative review. Journal of Chiropractic Medicine, 18(2), 115-126.

Martynov, V. O., Hladkyi, O. Y., Kolombar, T. M., \& Brygadyrenko, V. V. (2019a). Impact of essential oil from plants on migratory activity of Sitophilus granarius and Tenebrio molitor. Regulatory Mechanisms in Biosystems, 10(4), 359-371.

Martynov, V. O., Titov, O. G., Kolombar, T. M., \& Brygadyrenko, V. V. (2019b). Influence of essential oils of plants on themigration activity of Tribolium confusum (Coleoptera, Tenebrionidae). Biosystems Diversity, 27(2), 177-185.

Mehlhom, H. (2016). Vitex agnus castus. In: Mehlhorn, H. (Ed.). Encyclopedia of parasitology. Springer-Verlag, Berlin, Heidelberg. Pp. 3023-3023.

Mekonnen, A., Tesfaye, S., Christos, S. G., Dires, K., Zenebe, T., Zegeye, N., Shiferaw, Y., \& Lulekal, E. (2019). Evaluation of skin irritation and acute and subacute oral toxicity of Lavandula angustifolia essential oils in rabbit and mice. Journal of Toxicology, 2019, 5979546

Michel, J., Abd Rani, N. Z., \& Husain, K. (2020). A review on the potential use of medicinal plants from Asteraceae and Lamiaceae plant family in cardiovascular diseases. Frontiers in Pharmacology, 11, 852

Milevskaya, V. V., Prasad, S., \& Temerdashev, Z. A. (2019). Extraction and chromatographic determination of phenolic compounds from medicinal herbs in the Lamiaceae and Hypericaceae families: A review. Microchemical Journal, 145, $1036-1049$.

Miraj, S., Kopaei, R., \& Kiani, S. (2017). Melissa officinalis L.: A review study with an antioxidant prospective. Journal of Evidence-Based Integrative Medicine, 22(3), 385-394

Moradi, M. T., Rafieian-Kopaei, M., \& Karimi, A. (2016). A review study on the effect of Iranian herbal medicines against in vitro replication of herpes simplex virus. Avicenna Journal of Phytomedicine, 6(5), 506-515.

Moradkhani, H., Sargsyan, E., Bibak, H., Naseri, B., Sadat-Hosseini, M., FayaziBarjin, A., \& Meftahizade, H. (2010). Melissa officinalis L., a valuable medicine plant: A review. Journal of Medicinal Plants Research, 4(25), 2753-2759.

Naderi Dastjerdi, M., Darooneh, T., Nasiri, M., Moatar, F., Esmaeili, S., \& Ozgoli, G. (2019). Investigating the effect of Melissa officinalis on after-pains: A randomized single-blind clinical trial. Joumal of Caring Sciences, 8(3), 129-138.

Ngo, Y. L., Lau, C. H., \& Chua, L. S. (2018). Review on rosmarinic acid extraction, fractionation and its anti-diabetic potential. Food and Chemical Toxicology, $121,687-700$.

Noguchi-Shinohara, M., Ono, K., Hamaguchi, T., Iwasa, K., Nagai, T., Kobayashi, S., Nakamura, H., \& Yamada, M. (2015). Pharmacokinetics, safety and tolerability of Melissa officinalis extract which contained rosmarinic acid in healthy individuals: A randomized controlled trial. PloS One, 10(5), e0126422.

Oskouie, A. A., Yekta, R. F., Tavirani, M. R., Kashani, M. S., \& Goshadrou, F. (2018). Lavandula angustifolia effects on rat models of Alzheimer's disease through the investigation of serum metabolic features using NMR metabolomics. Avicenna Journal of Medical Biotechnology, 10(2), 83-92.

Ozarowski, M, Mikolajczak, P. L, Piasecka A, Kachlicki, P Kujawski, R, Bogacz, A., Bartkowiak-Wieczorek, J., Szulc, M., Kaminska, E., Kujawska, M., Jodynis-Liebert, J., Gryszczynska, A., Opala, B., Lowicki, Z., Seremak-Mrozikiewicz, A., \& Czerny, B. (2016). Influence of the Melissa officinalis leaf extract on long-term memory in scopolamine animal model with assessment of mechanism of action. Evidence-Based Complementary and Alternative Medicine, 2016, 9729818

Pal, M., Li, S. H., Tewari, S. K., \& Sun, H. D. (2013). Diterpenoid compounds from Vitex agnus-castus. Chemistry of Natural Compounds, 49(4), 635-638.

Park, B. Y., Lee, H., Woo, S., Yoon, M., Kim, J., Hong, Y., Lee, H. S., Park, E. K., Hahm, J. C., Kim, J. W., Shin, S. S., Kim, M. Y., \& Yoon, M. (2015). Reduction of adipose tissue mass by the angiogenesis inhibitor ALS-L1023 from $\mathrm{Me}$ lissa officinalis. PloS One, 10(11), e0141612.

Perry, R., Terry, R., Watson, L. K., \& Ernst, E. (2012). Is lavender an anxiolytic drug? A systematic review of randomised clinical trials. Phytomedicine, 19, 825-835.

Peterfalvi, A., Miko, E., Nagy, T., Reger, B., Simon, D., Miseta, A., Czéh, B., \& Szereday, L. (2019). Much more than a pleasant scent: A review on essential oils supporting the immune system. Molecules, 24(24), 4530. 
Raut, J. S., \& Karuppayil, S. M. (2014). A status review on the medicinal properties of essential oils. Industrial Crops and Products, 62, 250-264.

Ross, I. A. (2001). Vitex agnus-castus. In: Ross, I. A. Medicinal plants of the world Chemical constituents, traditional and modern medical uses. Humana Press, Totowa, NJ. Vol. 2. Pp. 427-435.

Saberi, A., Abbasloo, E., Sepehri, G., Yazdanpanah, M., Mirkamandari, E., Sheibani, V., \& Safi, Z. (2016). The effects of methanolic extract of Melissa officinalis on experimental gastric ulcers in rats. Iranian Red Crescent Medical Journal, 18(7), e24271.

Sadeghzadeh, J., Vakili, A., Bandegi, A. R., Sameni, H. R., Zahedi Khorasani, M., \& Darabian, M. (2017). Lavandula reduces heart injury via attenuating tumor necrosis factor-alpha and oxidative stress in a rat model of infarct-like myocardial injury. Cell Journal, 19(1), 84-93.

Safaeian, L., Sajjadi, S. E., Javanmard, S. H., Montazeri, H., \& Samani, F. (2016). Protective effect of Melissa officinalis extract against $\mathrm{H}_{2} \mathrm{O}_{2}$-induced oxidative stress in human vascular endothelial cells. Research in Pharmaceutical Sciences, 11(5), 383-389.

Safarabadi, A. M., Abbaszadeh, S., Sepahvand, H., \& Ebrahimi, F. (2018). An overview of the important analgesic herbs in Iran. Anaesthesia Pain and Intensive Care, 22(4), 522-528.

Saljoughian, S., Roohinejad, S., Bekhit, A. E. A., Greiner, R., Omidizadeh, A., Nikmaram, N., \& Khaneghah, A. M. (2018). The effects of food essential oils on cardiovascular diseases: A review. Critical Reviews in Food Science and Nutrition, 58(10), 1688-1705.

Samarth, R. M., Samarth, M., \& Matsumoto, Y. (2017). Medicinally important aromatic plants with radioprotective activity. Future Science OA, 3(4), FSO247.

Sammar, M., Abu-Farich, B., Rayan, I., Falah, M., \& Rayan, A. (2019). Correlation between cytotoxicity in cancer cells and free radical-scavenging activity: In vitro evaluation of 57 medicinal and edible plant extracts. Oncology Letters, 18(6), 6563-6571.

Samuelson, R., Lobl, M., Higgins, S., Clarey, D., \& Wysong, A. (2020). The effects of lavender essential oil on wound healing: A review of the current evidence. Journal of Alternative and Complementary Medicine, 26(8), 680-690.

Sedighi, M., Faghihi, M., Rafieian-Kopaei, M., Rasoulian, B., \& Nazari, A. (2019). Cardioprotective effect of ethanolic leaf extract of Melissa officinalis L. against regional ischemia-induced arrhythmia and heart injury after five days of reperfusion in rats. Iranian Journal of Pharmaceutical Research, 18(3), 1530-1542.

Seol, G. H., Lee, Y. H., Kang, P., You, J. H., Park, M., \& Min, S. S. (2013). Randomized controlled trial for Salvia sclarea or Lavandula angustifolia: Differential effects on blood pressure in female patients with urinary incontinence undergoing urodynamic examination. Journal of Alternative and Complementary Medicine, 19(7), 664-670.

Setzer, W. N. (2009). Essential oils and anxiolytic aromatherapy. Natural Product Communications, 4(9), 1305-1316.

Shabanian, G., Heidari-Soureshjani, S., \& Salcher, J. (2019). Effectiveness of medicinal herbs on psychological indices before and after surgeries. Plant Science Today, 6(3), 321-327.

Shakeri, A., Sahebkar, A., \& Javadi, B. (2016). Melissa officinalis L. - A review of its traditional uses, phytochemistry and pharmacology. Journal of Ethnopharmacology, 188, $204-228$.

Shin, S. S., \& Yoon, M. (2020). Regulation of obesity by antiangiogenic herbal medicines. Molecules, 25(19), 4549.

Shinjyo, N., \& Green, J. (2017). Are sage, rosemary and lemon balm effective interventions in dementia? A narrative review of the clinical evidence. European Journal of Integrative Medicine, 15, 83-96.

Shojaii, A., Ghods, R., \& Fard, M. A. (2016). Medicinal herbs in Iranian traditional medicine for learning and memory. African Journal of Traditional Complementary and Alternative Medicines, 13(2), 199-209.

Shokri, A., Saeedi, M., Fakhar, M., Morteza-Semnani, K., Keighobadi, M., Hosseini Teshnizi, S., Kelidari, H. R., \& Sadjadi, S. (2017). Antileishmanial activity of Lavandula angustifolia and Rosmarinus officinalis essential oils and nanoemulsions on Leishmania major (MRHO/IR/75/ER). Iranian Journal of Parasitology, 12(4), 622-631.

Sik, B., Kapcsandi, V., Szekelyhidi, R., Hanczne, E. L., \& Ajtony, Z. (2019). Recent advances in the analysis of rosmarinic acid from herbs in the Lamiaceae family. Natural Product Communications, 14(7), 1934578X19864216.
Stehbens, W. E. (1986). An appraisal of cholesterol feeding in experimental atherogenesis. Progress in Cardiovascular Diseases, 29(2), 107-128.

Stojković, D., Soković, M., Glamočlija, J., Džamić, A., Ćirić, A., Ristić, M., \& Grubišić, D. (2011). Chemical composition and antimicrobial activity of Vitex agnus-castus L. fruits and leaves essential oils. Food Chemistry, 128(4), 10171022.

Swiader, K., Startek, K., \& Wijaya, C. H. (2019). The therapeutic properties of lemon balm (Melissa officinalis L.): Reviewing novel findings and medical indications. Journal of Applied Botany and Food Quality, 92, 327-335.

Thomas, J. N., Kelley, M. J., \& Story, J. A. (1984). Alteration of regression of cholesterol accumulation in rats by dietary pectin. British Journal of Nutrition, 51(3), 339-345.

Todorov, D., Hinkov, A., Shishkova, K., \& Shishkov, S. (2014). Antiviral potential of Bulgarian medicinal plants. Phytochemistry Reviews, 13(2), 525-538.

Torki, M., Mohebbifar, A., \& Mohammadi, H. (2021). Effects of supplementing hen diet with Lavandula angustifolia and/or Mentha spicata essential oils on production performance, egg quality and blood variables of laying hens. Veterinary Medicine and Science, 7(1), 184-193.

Trivellini, A., Lucchesini, M., Maggini, R., Mosadegh, H., Villamarin, T. S. S., Vernieri, P., Mensuali-Sodi, A., \& Pardossi, A. (2016). Lamiaceae phenols as multifaceted compounds: Bioactivity, industrial prospects and role of "positivestress". Industrial Crops and Products, 83, 241-254.

Uritu, C. M., Mihai, C. T., Stanciu, G. D., Dodi, G., Alexa-Stratulat, T., Luca, A., Leon-Constantin, M. M., Stefanescu, R., Bild, V., Melnic, S., \& Tamba, B. I. (2018). Medicinal plants of the family Lamiaceae in pain therapy: A review. Pain Research and Management, 2018, 7801543.

Valizadeh, E., Ghalichi, F., \& Ostadrahimi, A. (2016). Traditional herbal medicine for weight management: A review. International Journal of Medical Research and Health Sciences, 5(11), 393-399.

Wang, D., Yuan, X., Liu, T., Liu, L., Hu, Y., Wang, Z., \& Zheng, Q. (2012). Neuroprotective activity of lavender oil on transient focal cerebral ischemia in mice. Molecules, 17(8), 9803-9817.

Woronuk, G., Demissie, Z., Rheault, M., \& Mahmoud, S. (2011). Biosynthesis and therapeutic properties of Lavandula essential oil constituents. Planta Medica, 77(1), 7-15.

Wynn, S. G., \& Fougère, B. J. (2007). Veterinary herbal medicine: A systems-based approach. Veterinary Herbal Medicine, 291-409.

Xu, P., Wang, K., Lu, C., Dong, L., Gao, L., Yan, M., Aibai, S., Yang, Y., \& Liu, X. (2017). The protective effect of lavender essential oil and its main component linalool against the cognitive deficits induced by d-galactose and aluminum trichloride in mice. Evidence-Based Complementary and Alternative Medicine, 2017,7426538

Yu, S. H., \& Seol, G. H. (2017). Lavandula angustifolia Mill. oil and its active constituent linalyl acetate alleviate pain and urinary residual sense after colorectal cancer surgery: A randomised controlled trial. Evidence-Based Complementary and Alternative Medicine, 2017, 3954181.

Zarei, A., Changizi Ashtiyani, S., Taheri, S., \& Rasekh, F. (2014). Comparison between effects of different doses of Melissa officinalis and atorvastatin on the activity of liver enzymes in hypercholesterolemia rats. Avicenna Journal of Phytomedicine, 4(1), 15-23.

Zazharskyi, V. V., Davydenko, P. O., Kulishenko, O. M., Borovik, I. V., \& Brygadyrenko, V. V. (2019). Antimicrobial activity of 50 plant extracts. Biosystems Diversity, 27(2), 163-169.

Zazharskyi, V. V., Davydenko, P. O., Kulishenko, O. M., Borovik, I. V., Zazharska, N. M., \& Brygadyrenko, V. V. (2020). Antibacterial and fungicidal activities of ethanol extracts of 38 species of plants. Biosystems Diversity, 28(3), 281-289.

Ziaee, M., Khorrami, A., Ebrahimi, M., Nourafcan, H., Amiraslanzadeh, M., Rameshrad, M., Garjani, M., \& Garjani, A. (2015). Cardioprotective effects of essential oil of Lavandula angustifolia on isoproterenol-induced acute myocardial infarction in rat. Iranian Journal of Pharmaceutical Research, 14(1), 279-289.

Zvezdina, E. V., Dayronas, J. V., Bochkareva, I. I., Zilfikarov, I. N., Babaeva, E. Y., Ferubko, E. V., Guseynova, Z. A., Serebryanaya, F. K., Kaibova, S. R., \& Ibragimov, T. A. (2020). Members of the family Lamiaceae Lindl. as sources of medicinal plant raw materials to obtain neurotropic drugs. Pharmacy and Pharmacology, 8(1), 4-28. 